\title{
القانون الواجب التطبيق على إنعقاد الزواج وإنتهائه \\ (دراسة تحليلية)
}

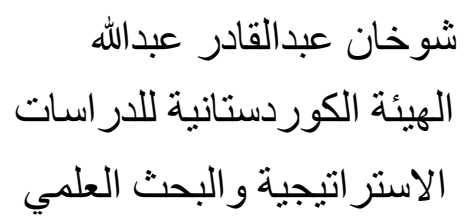

shoxan.abdullah@kissr.edu.krd

\author{
سلهنكهر علي رسول \\ جامعة رايهرين- قسم القانون \\ sangar.rasool@uor.edu.krd
}

المقدمة:

الزواج في الثريعة الإسلامية عقد يفيد استمتاع كل من المتعاقدين بالآخر شر عاً طلباً للنسل. وقد جاء في القرآن الكريم

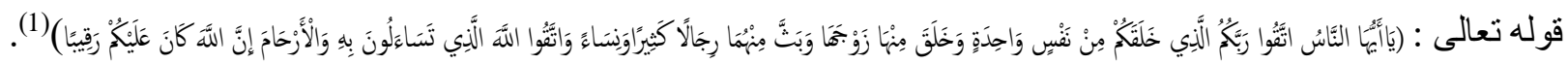
ولا فرق بين الأجنبي و الوطني بالنسبة لحق الزواج(2)، إلا أن كل مجتمع يستأثر بمفاهيم عائلية و أفكار أساسية خاصة به لتنظيم الرو ابط الأسرية يستمدها من أصوله الأخلاقية والدينية والاجتماعية ومثله العليا التي يستند إليها كيانه وديمو مته. ولهذا تعتبر هذه الروابط من النظام العام في كل جماعة، وكل دولة تقرر شروطها الموضو عية بمقتضى نظامها القانوني ضمن طائفة الحقوق الخاصة ذات العلاقة بالنظام العام.

الأصل في التصر فات القانونية الرضائية، ومع ذلك فإن أغلب التشريعات لا تكتفي أحياناً بإظهار الرضا لإنعقاد العقد بل

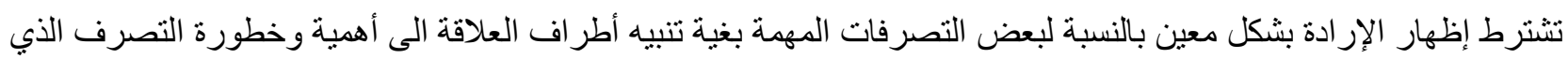
يقدمون عليه حتى يكون الغير على بينة و علم بمضمون التصرف، وقد يختلف فرض الثكلية من دولة الى أخرى، فإن ذلك يثير بلير التنازع بين قو انين الدول في شأن الثكل بما يلزم إخضاعه لاحد القو انين المتناز عة على حكمه، ويدور التنازع عادةً بين قانون محل إبر ام العقد وقانون جنسية أطر اف العلاقة أو قانون موطنهم وقانون بلد التنفيذ، ولحل هذا التناز ع لابد من تحديد القانون الو اجب تطبيقه على الثكلية المطلوبة في التصرفات القانونية.

كانت الدول في السابق لا تقبل بنطبيق القوانين الأجنبية على إقليمها، على اعتبار أن هذا العمل يتعارض مع مبدأ سيادة الدول لكن بنطور المدنية وظهور حركة تنقل الأشخاص والأمو ال أصبحت الدول تقبل بذلك على أساس منطق العدالة الاجتماعية و على أساس المعاملة بالمثل. و على إثر هذا التبادل القانوني بين الدول، بلغ التنازع ذروته خاصة في المسائل الأسرية ذات العنصر الأجنبي. لذلك وجدت قو اعد الإسناد(3) كوسيلة لفض التنازع الحاصل بين قو انين الدول المختلفة.

(1) الآية الأولى من سورة النساء. (2) تنص المادة (3/16) من الاعلان الأن العالمي لحقوق الإنسان على أن : (الأسرة هي الوحدة الطبيعية الأساسية للمجتمع ولها حق التمتع بحماية المجتمع والدولة) الدادة)

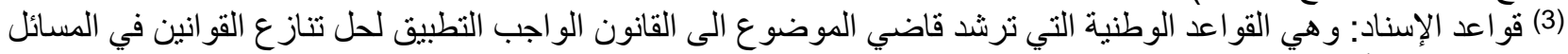

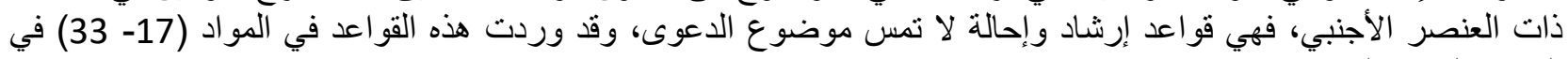


و الجدير بالذكر ، أن المجال الخصب لتناز ع القو انين يكون خاصة في المسائل الأسرية نظر الاختلاف عقائد وخصوصيات الأفر اد. وأمام هذا الوضع يثير الزواج مشاكل عدة من حيث انعقاده والآثار المترتبة عليه، والأمر كذلك بالنسبة لانحلال الزواج والآثار الناجمة عنه.

في ضوء ما ذُكر، سوف نقسم در استنا هذه الى مبحثين، خصصنا المبحث الأول للقانون الواجب التطبيق في المواضيع المتعلقة بإنعقاد الزو اج ومشكلاته، ونكرس المبحث الثاني لإنتهاء الزاوج و المواضيع المتعلقة به في قو اعد الإسناد.

\section{المفاتيح/}

القانون الواجب التطبيق , الثروط الموضو عية لعقد الزواج, اقو اعد الاسناد, القانون الأجنبي

\section{المبحث الاول}

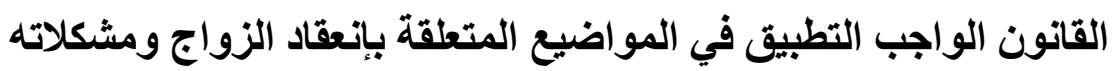

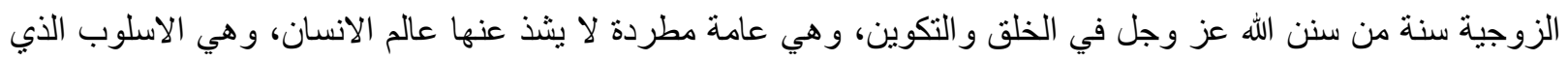

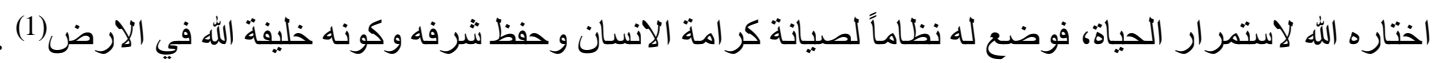

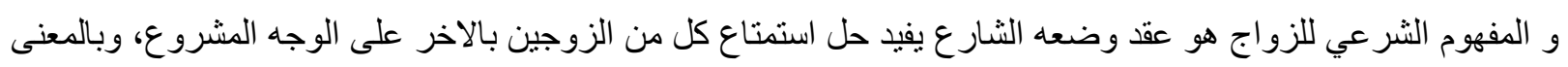

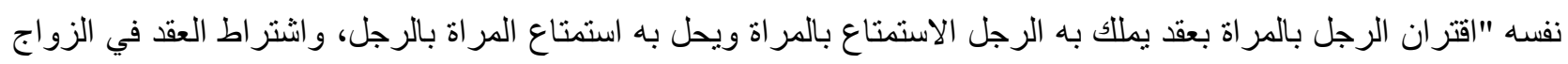
لتترتب عليه اثاره الثر عية كما تترتب على سائر العقود اثار ها"(2) .

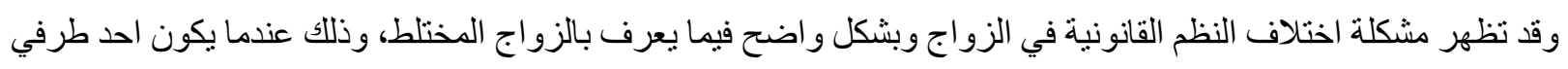

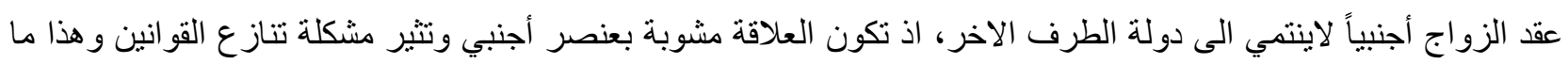

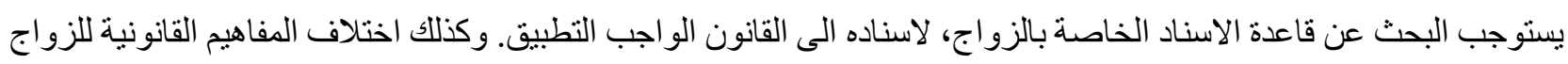
من دولة الى اخرى يساهم أيضاً في تعقيد مشكلة الزواج المختلط، فبعض الدول يأخذ بنظام الزواج المدني، في حين يأخذ البعض لأبل

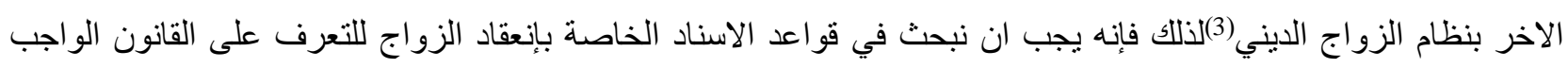
التطبيق عليه و عرض المشكلات التي تعترض تطبيق هذه القو اعد من خلال المطالب الاتية:

\section{المطلب الأول}

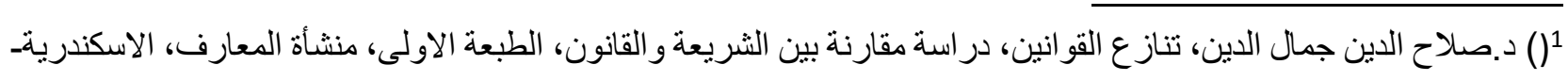

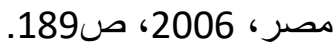

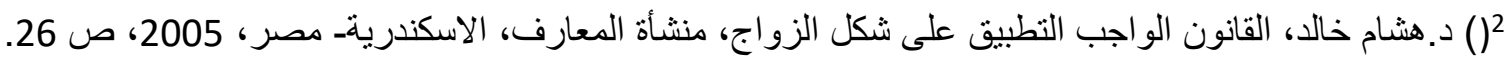

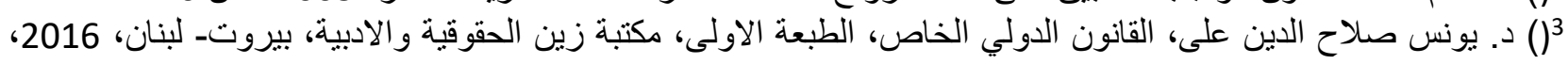




\section{الثروط الموضوعية للزواج والمواضيع المتعلقة بها الثانيا}

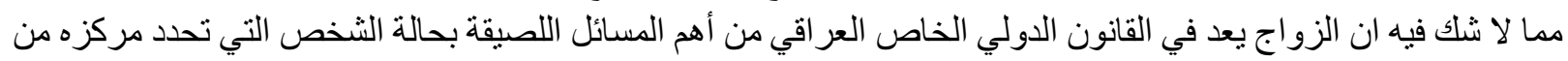
اسرته. ويجب ان يخضع بالتالي للقانون الثخصي، اي قانون جنسيته، ولكن الزواج على خلاف بقية المسائل المتعلقة بحالة

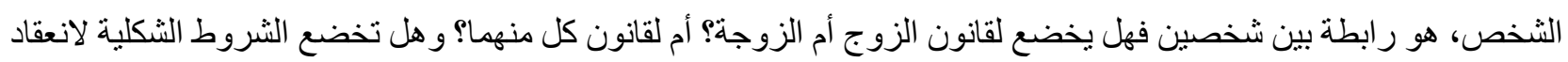

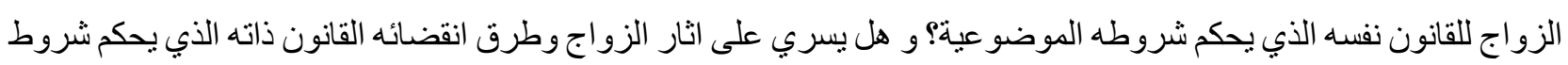

(1) (1)

من الجدير بالذكر ان نحدد نقطة عرض النزاع المتعلق بالزواج المختلط على المحكمة لتحديد القانون الواجب التطبيق بثأنها، فعندما يبدأ القاضي في تحديد الوصف القانوني للموضوع محل النزاع ثم يبدأ في البحث عن قاعدة الاسناد المناسبة لنطبيقها قبل الفصل في النزاع، اذ يتأثر ذلك الوصف بالدين و الظروف الاجتماعية السائدة في كل دولة، ومن ثم قد يختلف هذا المفهوم من بلد لاخر و هذا مايطلق عليه بلغة القانون التكييف القانوني و التي هي المرحلة التي تسبق ايجاد قاعدة الاسناد الخاصة بالتطبيق على فئى النزاع.

وفي القانون العر اقي نجد انه يرجع في تصنيف شروط الزواج لمعرفة ما اذا كانت هذه الشروط تعتبر من الثروط الثكلية ام

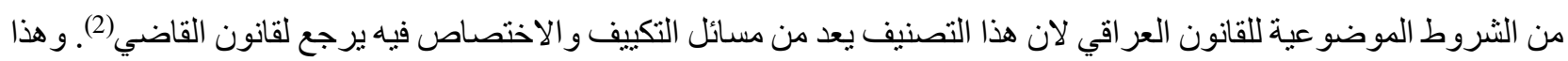

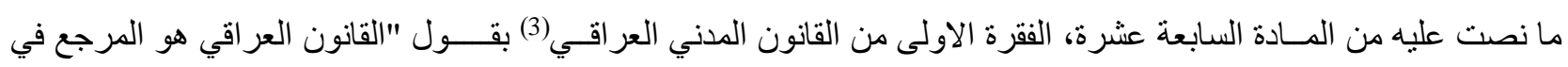
تكييف العلاقات عندما يتطلب تحديد نوع هذه العلاقات في قضية تتنازع فيها القو انين لمعرفة القانون الو اجب التطبيق من بينها".

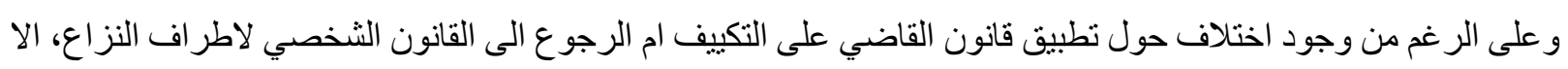

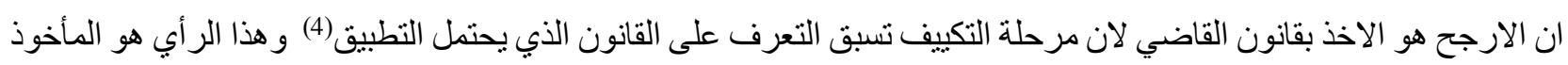
به في القانون العر اقي. لذلك سوف نقسم هذا المطلب الى الفرعين التاليين:

\section{الفرع الاول \\ ماهية(نطاق) الثروط الموضوعية الاول}

الثرط الموضوعي هو ما يتوقف وجود الثيء على تحقيقه(5)، ويعد من الشروط الموضو عية الخاصة بالار ادة كتوفر الاهلية(6) و الرضا وتطابق ارادتي العاقدين واتحاد مجلس الايجاب والقبول وعدم رجوع الموجب قبل القبول. وكذللك بعد من الثروط

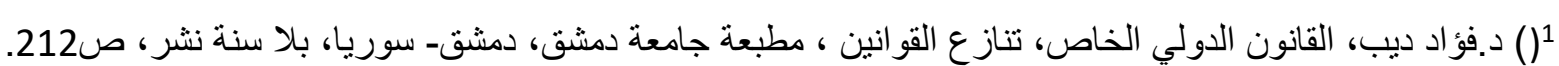

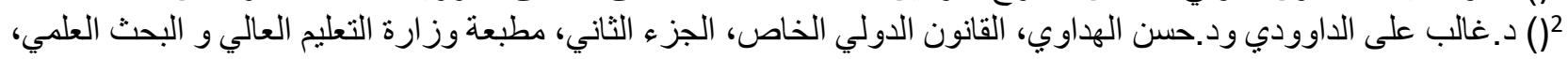

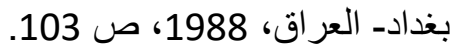

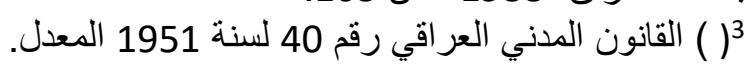

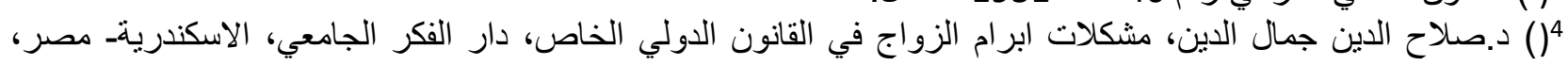
2010، ص صداح الاين 15 5 5) د. حسن الهداوي، 15. تنازع القو انين، المبادئ العامة و الحلول الوضعية في القانون الاردني، در اسة مقارنة، الطبعة الاولى، دار

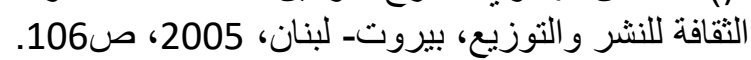

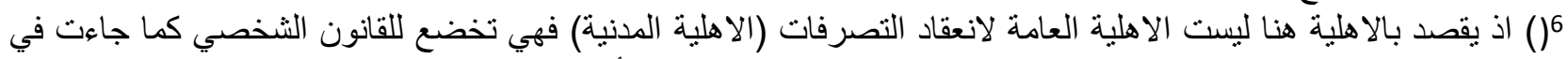

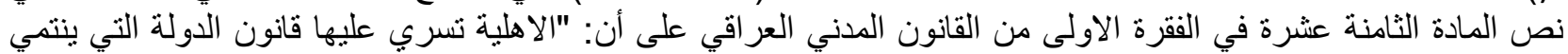

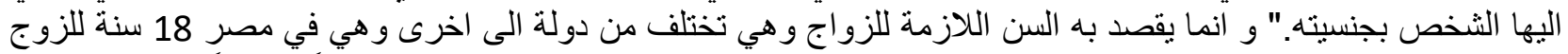

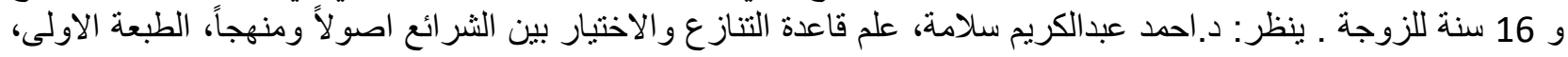

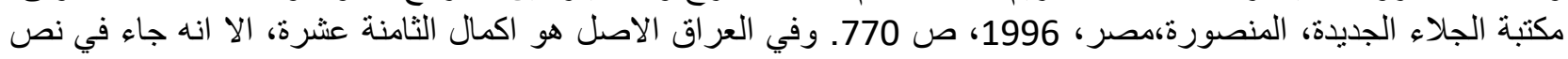
المادة الثامنة في قانون الاحو ال الثخصية العر اقية رقم 188 لسنة 1959 المعدل على النه:" يحق لمن اكمل الخامسة عشرة من النّاء 
الموضو عية ما تعلق منها بالمحل، و المحل في عقد الزواج هو صلاحية المر اة لان تكون محلا للعقد اي ان تكون غير محرمة على

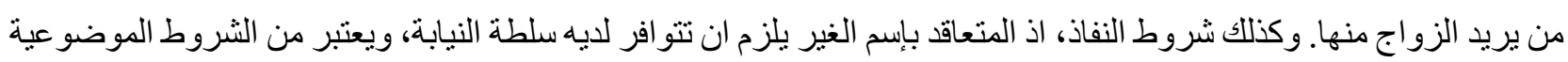

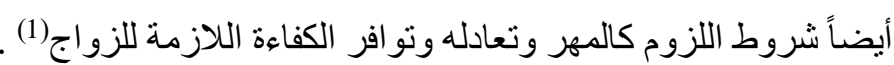
أما شرط الاشهاد على الزواج و على الرغم من وجود اراء مختلفة في الفقه الاسلامي حول اثر شرط الاشهاد بمعنى هل هو

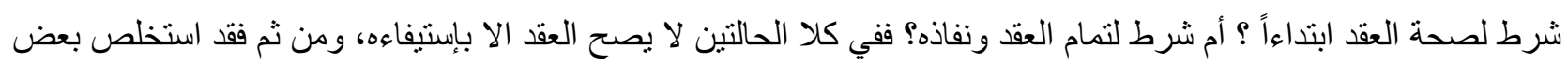
الفقهاء (2) بأن شرط الاشهاد من الثروط الثكلية ومن ثم فأن عقد الزو اج في الاسلام من العقود الثكلية وان كان الرضا اساساً فيه. الا ان الشكلية فيه عرفية غير رسمية . وبالنسبة لعقد الزواج تعتبر الثروط الموضو عية من أهم الثروط التي يتعلق بها الزواج بالصحة او البطلان، فهي من ماهية العقد. فبعد تحديد الثروط الموضو عية وما يدخل ضمن نطاقه لابد من تحديد القانون الو اجب التطبيق عليه وكذلك بيان قاعدة الاسناد

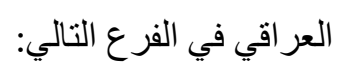

\section{الفرع الثاني \\ القانون الواجب التطبيق على الشروط الموضوعية الثيأي}

بعد تحديد ما يعد من الثروط الموضو عية نصل الى مرحلة تحديد القانون الواجب التطبيق التبروطيق عليها في عقد زواج ذات عنصر أجنبي، فإذا لم تكن العلاقة مشوبة بعنصر أجنبي نطبق قانون القاضي دون اللجوء الى قواعد الاسناد، أما في حالة الزواج المختلط فلا بد من اللجوء اليها لتحديد القانون الواجب التطبيق من بين القو انين المرشحة حسب العناصر الاجنبية الموجودة في العلاقة.

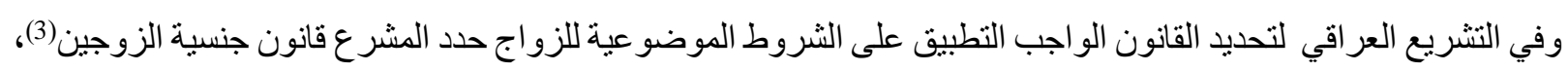

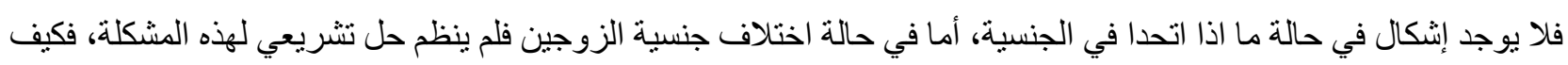
نو اجه تللك المشكلة وماهي الحلول التي عرضت من قبل الفقه لحسمها؟ إذ أخذ المشرع بضابط الجنسية كما هو الحال في كافة

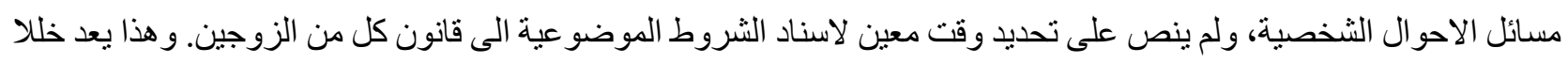

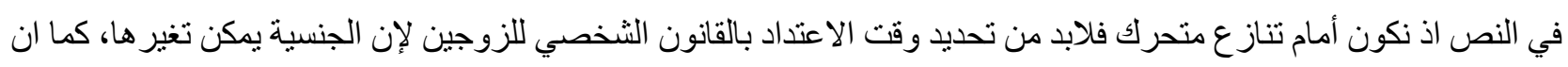

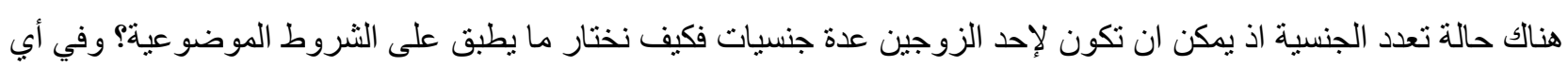
وقت؟ فقد يمكن ان يكون للشخص على سبيل المثال جنسية ألمانية و اخرى فرنسية عند إبرام العقد وبعد مدة يتخلى عن الجنسية الجنية الفرنسية، فأي قانون بطبق على تلك العلاقة؟

العمر تقديم الطلب للقاضي للزو اج اذا اثبت له اهليته و قابليته البدنبة وبعد مو افقة وليه الثرعي، وكذللك للقاضي ان يأذن بزواج

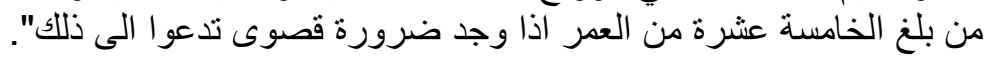

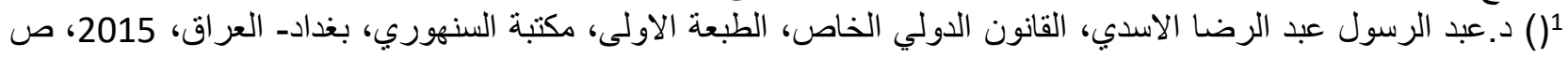

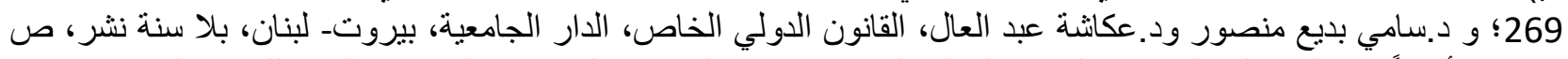

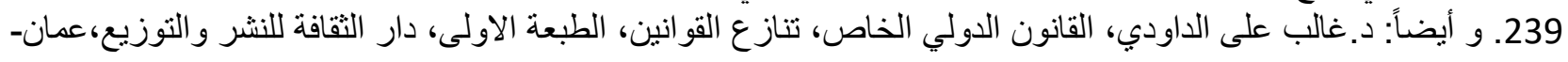

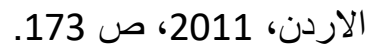

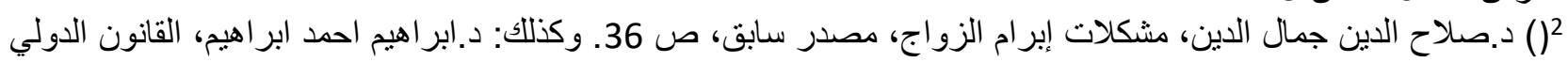

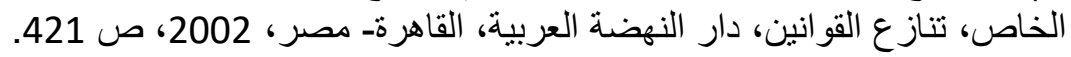

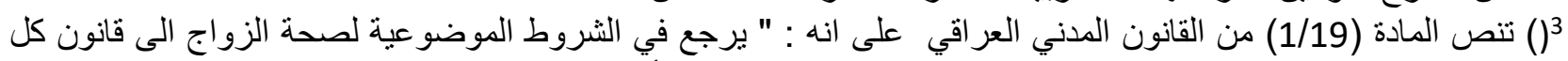

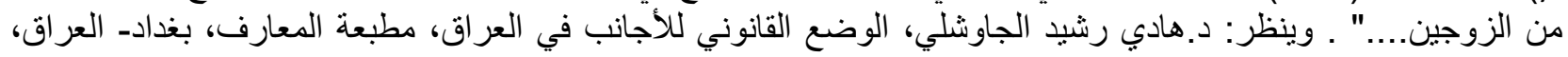
1961، ص ص 56. 
فبالعودة الى جانب من الفقه(1) نجد ان اخضاع الثروط الموضو عية للزواج الى قانون جنسية كل من الزوجين يكون وقت انعقاد الزواج لا وقت النزاع بإعنباره الوقت الذي ينبغي فيه اكتمال الثروط. أما في حالة تعدد الجنسيات لاحد اطر اف العلاقة فاذا كانت احدى هذه الجنسيات عر اقية فيختار فيما بين الجنسيات الاخرى الإى

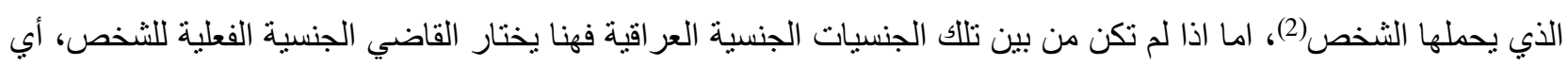
الجنسية الاكثر ارتباطاً بالشخص بحيث ينظر الى موطنه ومكان عمله او در استه يختار فيما بينهم، و هذا ما نستخلصه من مبادئ

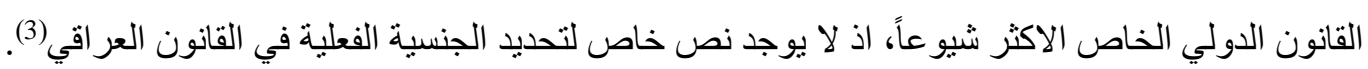
لكن بالعودة الى تطبيق قانون كل من الزوجين هناك سؤ ال مطروح الا و هو كيف يمكن تطبيق قانون جنسية كل من الزوجين

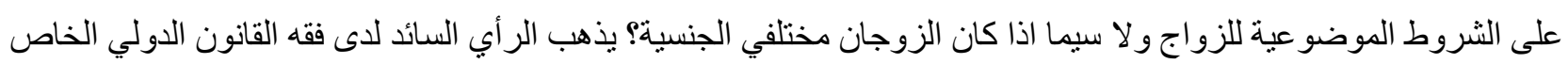

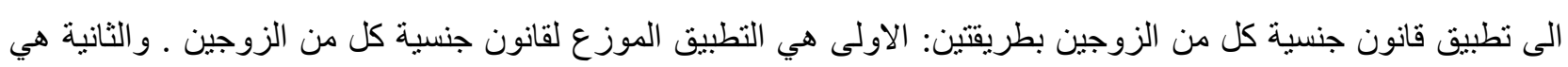

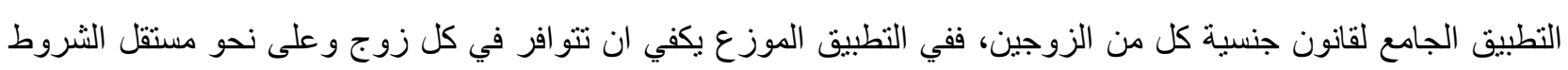

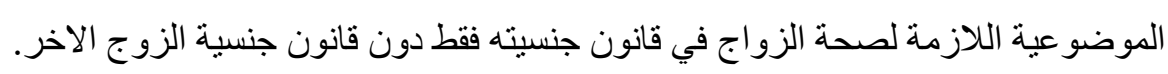
أما التطبيق الجامع فيقصد به ضرورة ان تتوفر في كل زوج من الزوجين كافة الشروط الموضو عية التي يتطلبها قانون دولته وقانون دولة الزوج الاخر . و الحكمة في التطبيق الجامع لقانون جنسية كل من الزوجين هي التأكد من بناء الاسرة على أساس سليم،

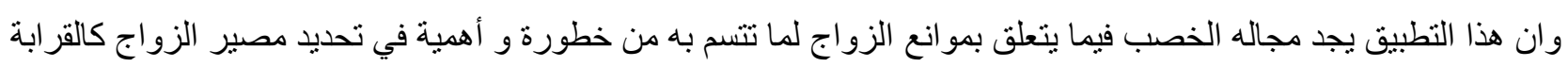

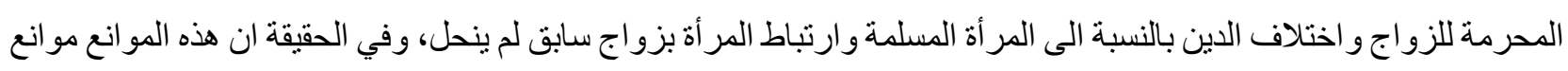

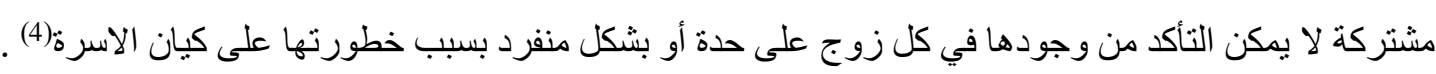

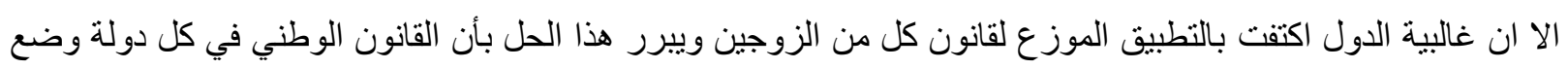
ليحمي مصالح أفراده فقط دون سو اهم و لا يرمي الى حماية الاسرة أو العلاقة الزوجية ذاتها، حتى يسري على غير الوطنيين، ولان

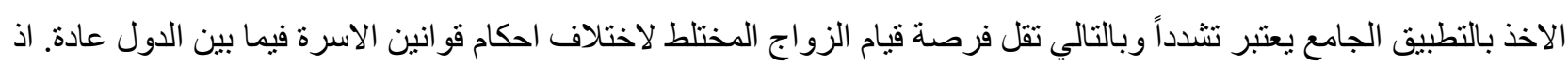
يكفي بأن يظل التطبيق الجامع صالحاً بخصوص موانع الزواج اذ ان التطبيق الموزع في وجود هذه الموانع يسمح بقيام رابطة الزوجية وهذا غير مقبول لسببين، الاول ان تلك الموانع ترمي الى قيام أسرة شر عية، ومن ثم حماية مصلحة عامة للمجتمع، ويلزم

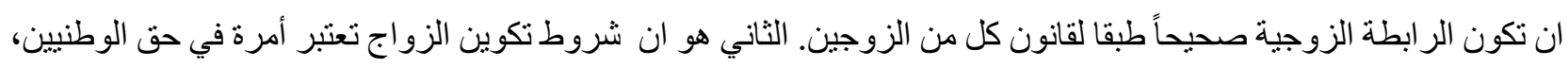

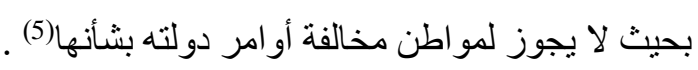

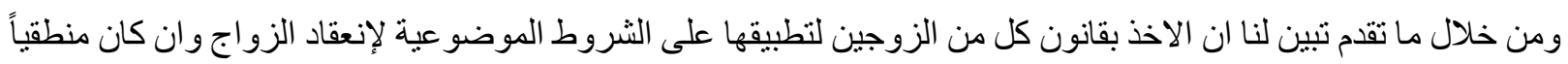
الا انه يجب تحديد كيفية تطبيقها فيما اذا كان الزوجان مختلفي الجنسية، وخصوصاً بيان كيفية الاخذ بالتطبيق الجامع والتطبيق

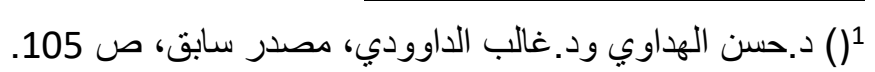

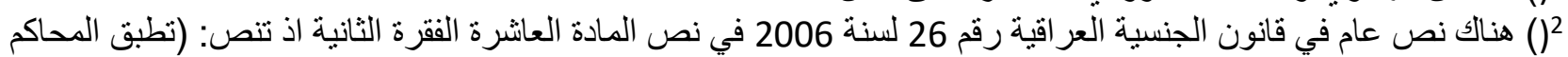

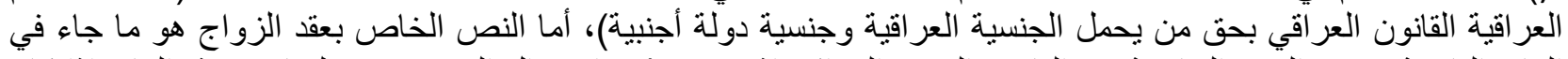

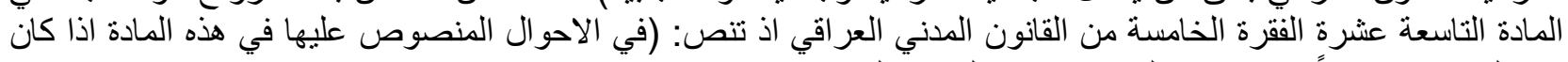

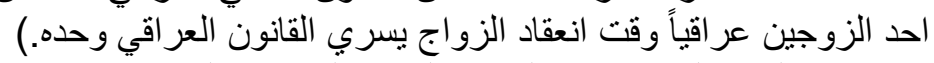

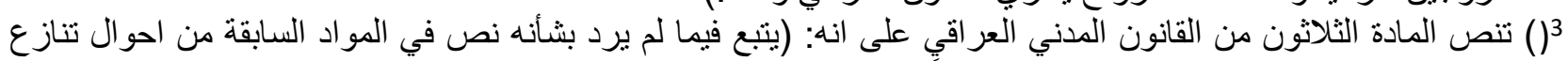

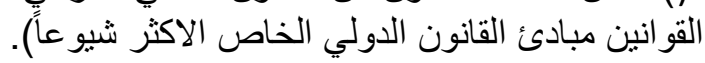

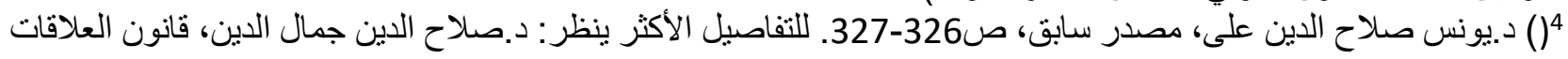

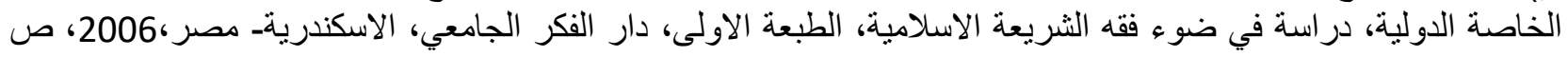


الموزع، بحيث يرد نص خاص بتحديد القانون الواجب التطبيق على الثروط الموضو عية لإنعقاد الزواج ويحدد فيه وقت الاخذ بقانون كل من الزوجين الاو هو وقت الإنعقاد، وكذلك تحديد ما يدخل من الثروط في التطبيق الجامع وما يدخل ضمن التطبيق لإنيق

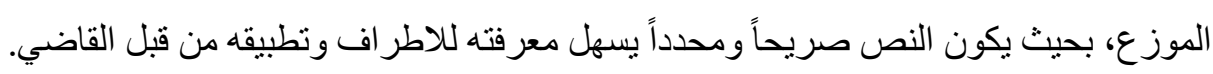
أما بشأن تغيير الجنسية لإحد الزوجين، هنا لا تثور مشكلة الغش نحو القانون اذا حدد في النص الاخذ بقانون كل من الزوجين

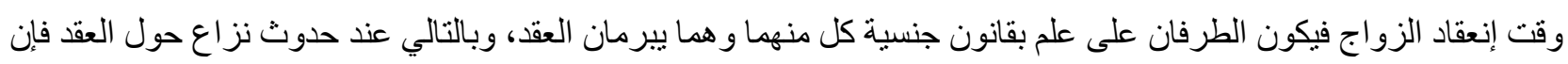

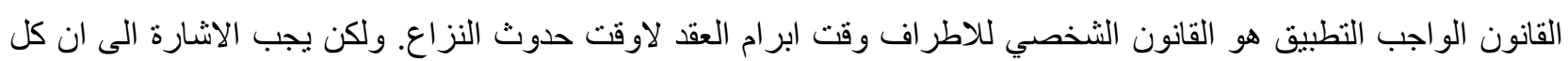
قضية تطبق المحكمة فيها قانوناً أجنبياً، أي عندما يككن النزاع المعروض أمام القضاء مشوباً بعنصر أجنبي هناك إحتمال إستبعاد ذللك القانون ونطبيق قانون القاضي وذلك في حالة ما اذا كان مخالفاً للنظام العام العر اقي(1).

\section{المطلب الثاني \\ الشروط الثكلية والقانون الواجب التطبيق عليها}

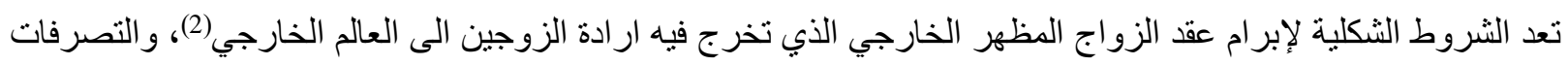

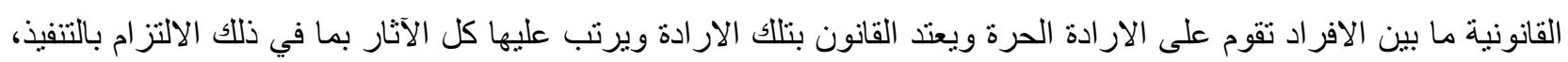
ولكي تظهر تلك الار ادة الى العالم الخارجي ينطلب المشرع اتخاذ بعض الاجر اءات و الاساليب او الاشهار و العلم من قبل أصحاب العلاقة، وان الغرض من الثكلية في الزواج هو العلم و العلانية لترتيب حقوق الاطر اف و الغير و المجتمع وبعد ذلك وسيلة اثبات

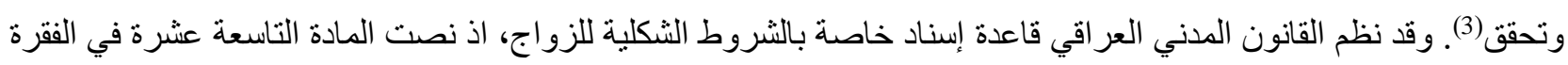
الاولى منه على انه : (...أما من حيث الثكل فيعتبر صحيحاً الزواج مابين أجنبيين أو مابين أجنبي و وعر اقي اذا عقد وفقاً للشكل المقرر في قانون البلد الذي تم فيه، أو اذا روعيت فيه الاشكال التي قررها قانون كل من الزوجين) وسوف نتناول مضمون هذه القاعدة الخاصة بالشروط الثكلية للزو اج في الفروع الاتية:

\section{الفرع الاول}

\section{قانون البلد الأي تمَّ فيه العقد (قانون بلأل الإبرام)}

ان شكل التصرف القانوني يخضع بحسب الاصل الى قانون البلد الذي تم فيه، وبالتالي فإن الثروط الثكلية للزواج تخضع كأصل عام أيضاً الى قانون البلد الذي انعقد فيه هذا الزواج، حيث يرجع الى هذا البلد لبيان فيما اذا كان الزواج قد تو افرت له شروط صحته من الناحية الشكلية اذا كان هذا البلد يقرر اخر اج الزواج بشكل أو وسيلة معينة كالتسجيل المدني أو التوثيث من المر اجع المختصة(4)، و هذه القاعدة العامة في اسناد شكل التصرف الى قانون دولة الابر ام أخذ به المشرع العر اقي في نص المادة السادسة و العشرين من القانون المدني العر اقي

11) تتص المادة 32 من القانون المدني العر اقي على انه: (لايجوز تطبيق احكام قانون أجنبي قررته النصوص السابقة اذا كانت

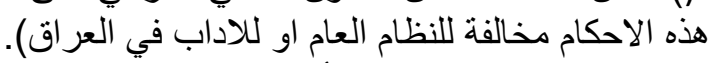

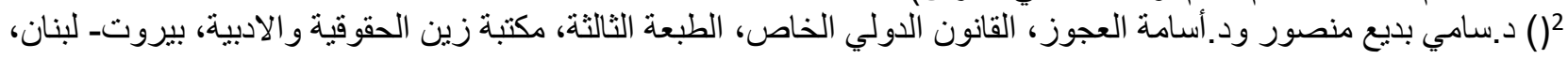

2009، ص د د253.

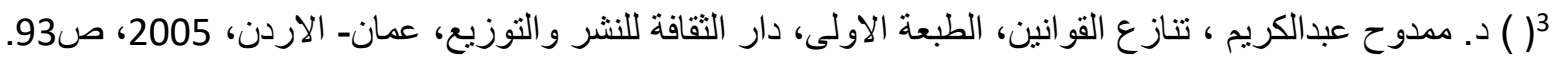

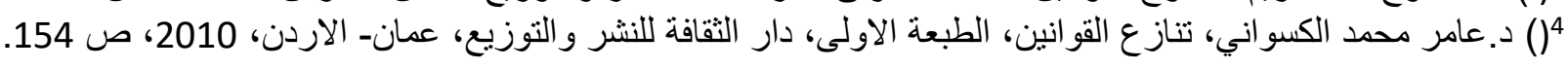


بحيث نص على انه: (تخضع العقود في شكلها لقانون الدولة التي تمت فيها.) فإذا تزوج أجنبيان في العراق احدهما تركي الجنسية والاخر ألماني الجنسية وتم ابر ام العقد في العراق، فمن الناحية الثكلية يعد الزواج صحيحاً اذا رو عيث فيه الثكل الو اجب اتباعه في القانون العراقي، اذ لايتطلب القانون العر اقي شكل رسمي معين، أو مر اسيم دينية، انما يكتفي فقط بإتخاذ الاجر اءات القانونية اللازمة لإجراء العقد. و هذه القاعدة لها مبرر الا و هي ان إثهار الزواج في شكل معين يتصل أكثر بعملية انشاء أو قيام الزواج،

وليس بإستمر اره، ومن ثم يجب تطبيق قانون محل الإنشاء (1)

\section{الفرع الثاني \\ قانون كل من الزوجين}

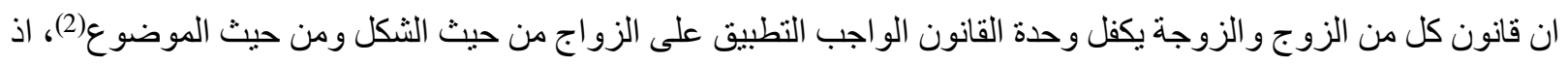

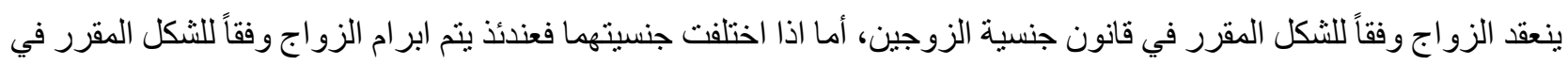
قانون كل منهما(3) ، فزواج فرنسيين في تركيا امام القنصل الفرنسي في انقره وفقاً للقانون الفرنسي يعتبر صحيحاً بمر اعاة الثكل

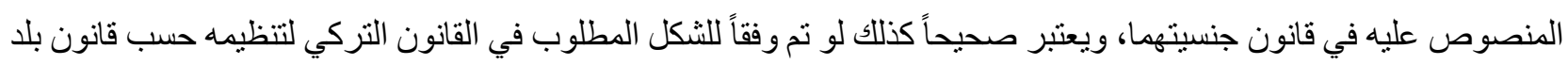
ابرام العقد. و كذلك لو كان احد الزوجين عر اقي الجنسية فيعمل بنفس القاعدة السالفة للذكر، فوجود طرف عرد عر اقي في عقد الزواج

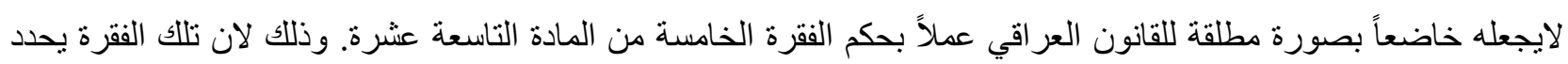
الفقرات الاخرى في المادة عدا الجزء المتعلق منها بشكل العقد بحيث يخرج من هذا الحكم وذللك لان المشر ع لو ار اد شموله بها ونها ونه لما افرده(4)، واستثنى الفقرة المتعلقة بالثكل عن تللك التي تتعلق بالثروط الموضوعية ما معناه ان بظهر التعارض بين الفقرة الخامسة و الفقرة الاولى الخاصة بالثروط الثكلية والتوفيق يكون بالثكل الاتي: ان ما ورد في الفقرة الخامسة بعتبر حكماً عاماً

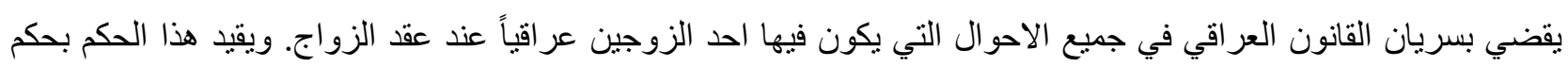
خاص وهو المتعلق بشكل عقد الزواج، فأجاز المشرع عقد الزواج وفقاً للشكل المقرر في البلد الذي تم فيه حتى ولو كان احد احد الزوجين عر اقياً(5) . ومن الجدير بالذكر ان هناك نوعاً اخر من شكل الزواج يسمى بالثكل القتصلي وهو ان يبرم الاجانب الزواج امام القتصلين

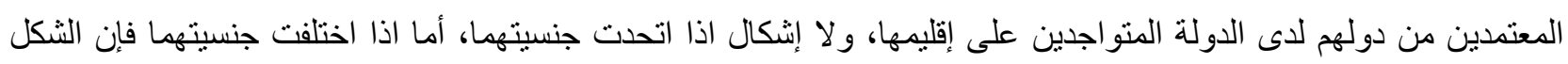

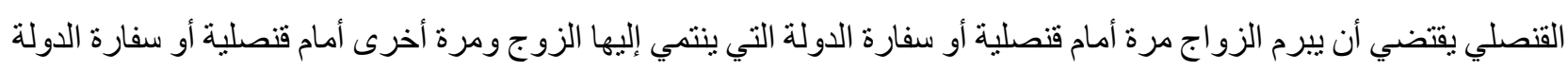

$$
\text { التي تنتمي إليها الزوجة(6). }
$$

وبعد عرض ما تقدم من القو انين الواجبة التطبيق على شكل الزواج لابد من الاشارة الى ان المشرع العر اقي عندما اخذ بقانون

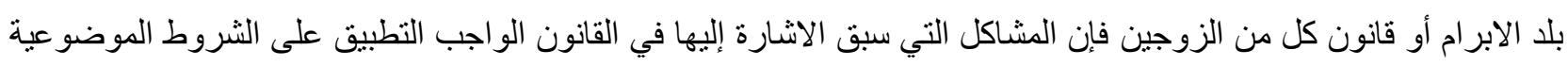

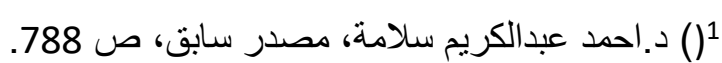

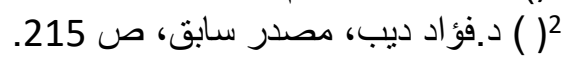

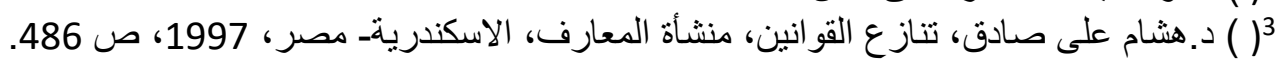

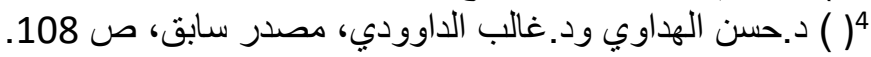
5 () ) المصدر نفسه، ص الد 109.

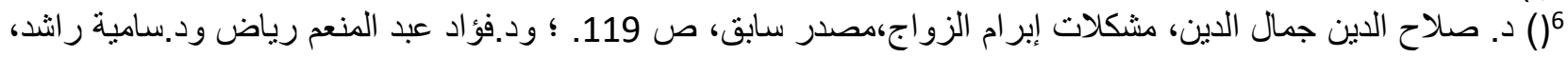

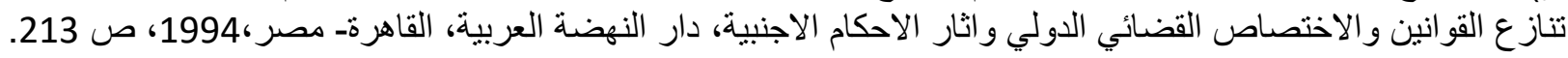


للزواج حين ذكر قانون كل من الزوجين هي نفسها التي تثور هنا أيضاً، فقانون كل من الزوجين يطبق في أي وقت؟ فانه يجب

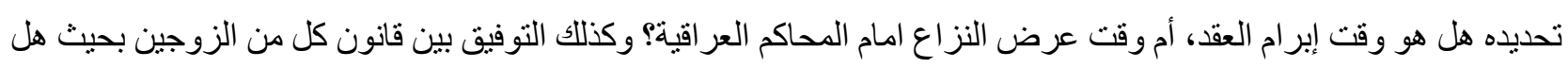

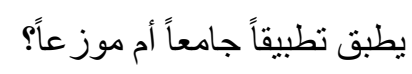

\section{المطلب الثالث \\ إثبات الزواج والقانون الواجب التطبيق عليه}

هناك جدل بين فقهاء القانون الدولي الخاص حول القانون الواجب التطبيق على إثبات الزواج، حيث اتجه البعض الى إخضاع إثبات الزواج لقانون القاضي بحجة إعتبار الإثبات مسألة إجرائية يجب خضو عها للقانون الذي يحكم الاجر اءات و هو قانون القاضي، غير ان البعض الاخرقد فضل خضوع إثبات الزواج للقانون الذي

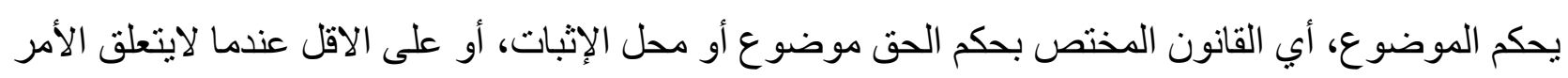
بإجر اءات تقديم الدليل، وذهب فريق ثالث الى إختصاص القانون الذي يحكم اثار الزواج(1) . ويرجع في إثبات الزواج الى القو اعد العامة و بالوسائل المقررة في القانون الذي يحكم الثكل وذلك بناءاً على الصلة التامة بين إنثاء العقد و كيفية إثباته، وهذا ما يؤدي الى تحكيم قانون محل إنعقاد الزواج اذا اتبعت الشكلية المقررة في قانون المحل و تحكيم قانون كل من الزوجين اذا عقد الزواج وفقاً للثكل المقرر في قانونهما في كل ما يتعلق بإثبات الزواج كتقديم الدليل الكتابي (2) أو الإكتفاء بالبينة الثخصية(3). و عليه اذا ابرم الزواج و اتبع فيه الثكل المقرر في قانون دولة الابرام يكون دعوى إثبات الزواج مقبو لاً ولا بحكم القاضي بعدم سماع دعوى لإلى الزوجية. ولا يوجد نص محدد في القانون العر اقي يحدد إختصاص قاعدة معينة بإثبات الزواج، ولكن جاء في قانون الاثبات المادة الثالثة عثرة الفقرة الاولى منه على ان: (يسري في شأن ادلة الإثبات قانون الدولة التي تم فيها التصرف القانوني، ومع ذلك يجوز للمحكمة أن تطبق القانون العر اقي إذا كان دليل الإثبات فيه أيسر من الدليل الذي يشترطه القانون الاجنبي)(4). ومن خلال النص يتبين لنا انه اذا تم إبر ام عقد الزواج في دولة السويد مثلاً بين شخصين وحدث نز اع حول إثبات العقد وعرض هذا النزاع أمام القضاء العر اقي في هذه الحالة يرجع القاضي الى القانون السويدي بشأن ما يجب ان يثبت به عقد الزواج من الادلة و البيانات، ولكن عند العودة الى ذلك

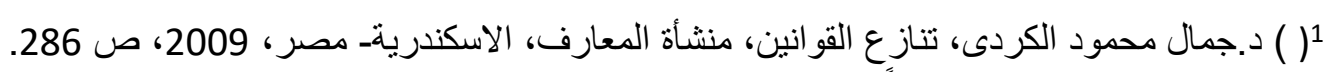

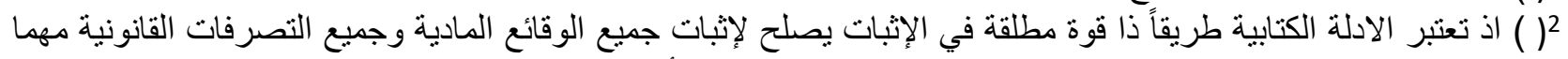

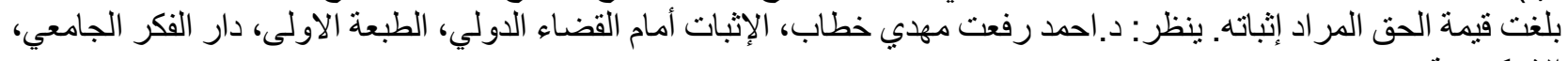

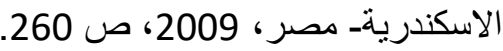

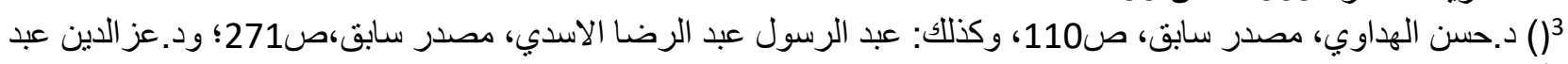

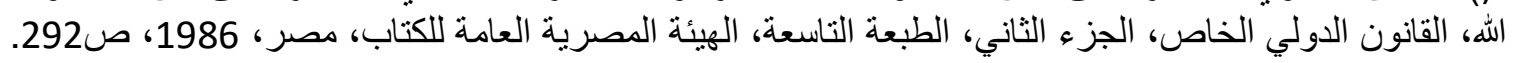

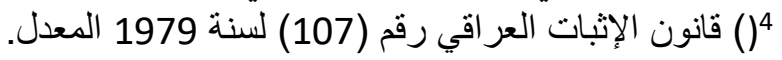


القانون وتحديد ما يتطلب من البيانات وكان من الايسر أو الاسهل اللجوء الى ادلة الإثبات في القانون العراقي، هنا يجوز للمحكمة ان بطبق القانون العر اقي بشأن ادلة الإثبات بدلاً من القانون السويدي. ولكن ما سبق ذكره هو إخضاع الإثبات للقانون الذي يحكم الثكل وفقاً للقو اعد العامة المتبعة الا وهي إخضاع الثكل لقانون محل ابر ام التصرف، أما اذا ابرم العقد واتبع الثكلية المتبعة وفقاً لقانون كل من الزوجين هنا يجب الزب إنب الرجوع الى القو اعد العامة او قو اعد القانون الدولي الخاص الاكثر شيوعاً. فعلى سبيل المثال اذا ابرم زوجان تركيان عقد زو اجهما في إيطالياو اتبعو ا في إبرام عقدهم القانون التركي بشأن الثروط الثكلية في العقد، وحدث نزاع حول إثبات الزواج و عرض أمام المحاكم العراقية. هنا تخضع مسألة الإثبات لقانون كل من الزوجين بإعتباره القانون المتبع لشكل عقد الزواج المبرم. اذ لابد من الاستعانة بأدلة لإثبات الزواج وهذه الادلة تختلف بإختلاف الدول اذ تلحق مسألة إثبات عقد الزواج من حيث القانون الواجب التطبيق بمسألة شكل الزواج للصلة الوثيقة بينهما وذلك وفق الاتجاه السائد في أكثر دول العالم(1) ، ويسري هذا القانون على الدليل المعد للإثبات وقوة هذا الدليل في الإثبات بإستثناء اجر اءات تقديمه الى القضاء(2) اذ تخضع لقانون القاضي عملاً بالقاعدة العامة المتعلقة بالقانون الواجب التطبيق على الإجراءات(3) . و من الجدير بالذكر انه يحق للقاضي استبعاد القانون الواجب التطبيق على إثبات الزواج اذا كان هذا القانون مخالفاً للاسس الجوهرية للمجتمع ومخالفاً للنظام العام(4)، ولكن يرى جانب من الفقه المصري(5) انه في حالة التوسع في استخدام فكرة النظام العام لاستبعاد احكام القوانين الاجنبية المختصة بموجب قو اعد الاسناد المصري و التوصل بذلك الى تطبيق الاحكام الموضو عية في القانون المصري، لما يؤدي اليه هذا الوضع من تعطيل لتنظيم التنازع و إهدار للحكمة التي تهدف إليها قو اعده.

\section{المبحث الثاني \\ إنتهاء الزواج والمواضيع المتعلقة به في قواعد الاسناد}

ينتهي الزواج إما بطريقة غير إرادية وهي الوفاة أو إرادية كالطلاق وهو حل الرابطة الزوجية بإرادة أحد الزوجين، وكذلك

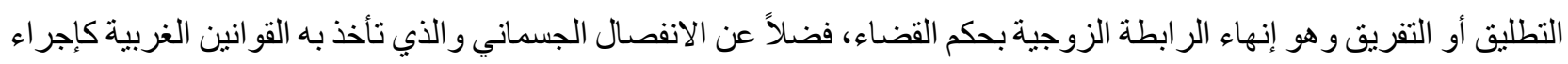

1) اذ تنص المادة 39 من القانون رقم 5 لسنة 1961 الكويني الخاص بتنظيم العلاقات القانونية ذات العنصر الاجنبي على انه:

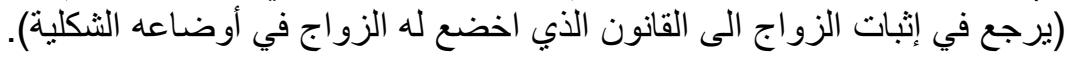

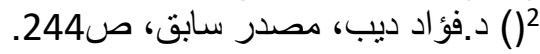

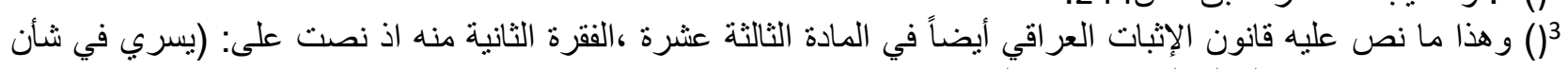
اجر اءات الإثبات قانون الدولة التي تقام فئان التانيا الدعوى).

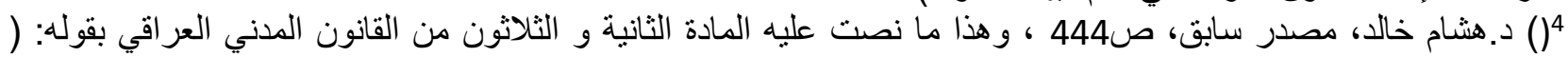

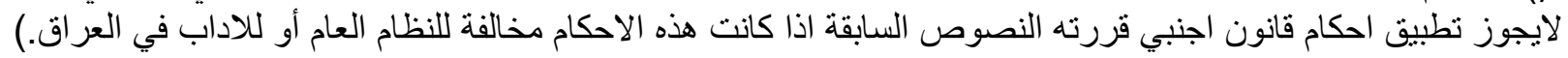

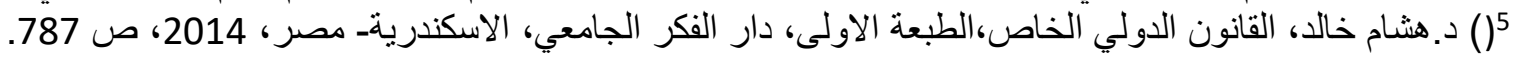


وقائي يقصد به المباعدة بين الزوجين كخطوة أولى مع بقاء الرابطة الزوجية قائمة دون المعيشة المشتركة لمدة معينة تتنهي أما

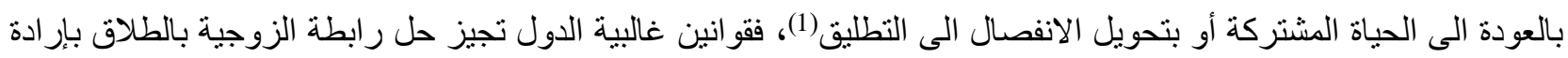

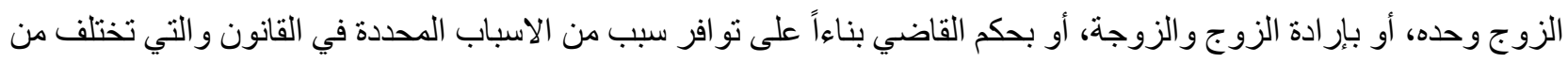
دولة الىى أخرى. ويرجع ذلك الاختلاف الى الفكرة الاجتماعية و المبادئ الخلقية التي ينهض عليها الزواج، وكذللك الاعتبار ات الدينية التي تركت أثر ها في الزواج في البلاد التي جعلت منه نظاماً مدنياً. وهذا ماجعل لكل هذه العو امل أثرها أيضاً في تحريك فكرة النظام العام في شأن تضييق نطاق تطبيق القانون الاجنبي الواجب التطبيق وتعطيله في شأن مدى الاحتجاج بالطلاق الذي تم في (الخارج) لذلك تتطلب در اسة إنتهاء الزو اج وتحديد قاعدة الاسناد له في هذا المبحث ان نقسمه الى ثناثة مطالب، نتناول في المطلب الاول قاعدة الاسناد الخاصة بإنتهاء الزواج، أما في المطلب الثاني فنبين نطاق تطبيق القانون الذي يحكم انتهاء الزواج، وفئ وفي المطلب

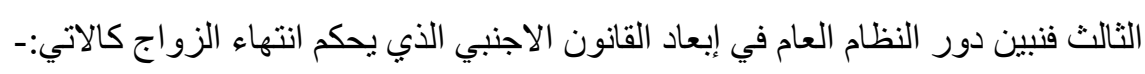

\section{المطلب الاول \\ قاعدة الاسناد الخاصة بإنتهاء الزواج الأب}

لتحديد قاعدة الاسناد الخاصة بإنتهاء الزواج يقتضي بيان المقصود بإنتهاء الزواج أولاً، وكذلك عرض مضمون القاعدة ثانباً وذللك في فرعين كالتالي:-

\section{الفرع الاول \\ المقصود بإنتهاء الزواج}

الزواج كأي تصرف قانوني اخر ينتهي وفق طرق معينة كالوفاة أو رضائية كالطلاق خارج المحكمة من قبل الزوج أو الزوجة

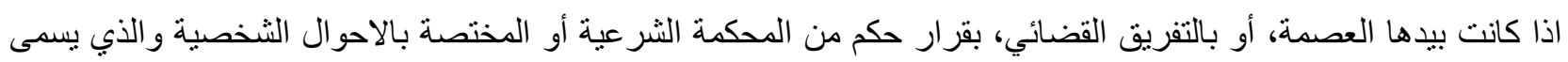
بالتطليق، أما حالة النشوز في الفقه الاسلامي وحالة الانفصال الجسماني في الفقه الغربي فلا ينتهي بهما الزواج. بل انهما لا يعدوان

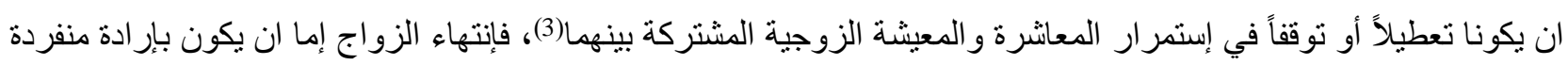
لإحد الزوجين ويسمى بالطلاق، أو قد يستلزم تدخل القضاء بناءاً على طلب احد الزوجين و هو ما يعرف بنظه بنظام التطليق.

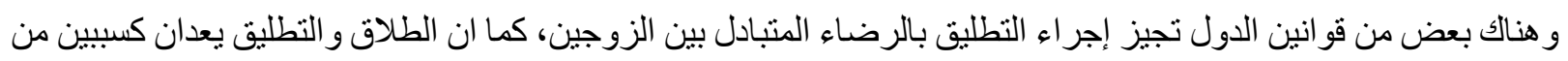

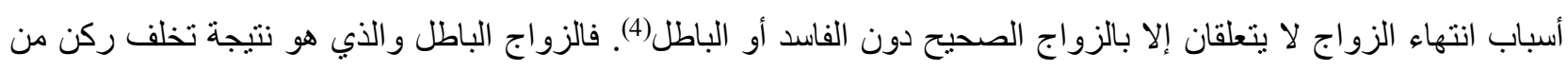

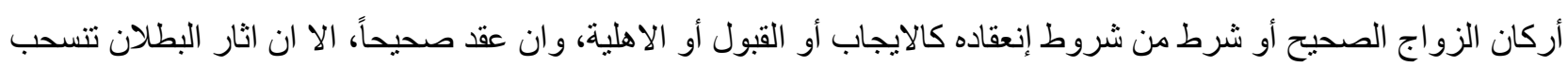

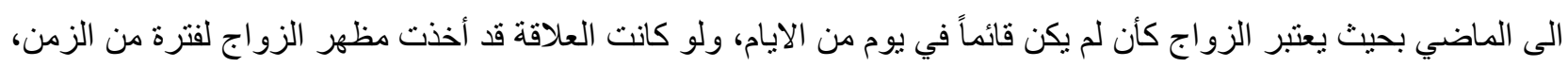

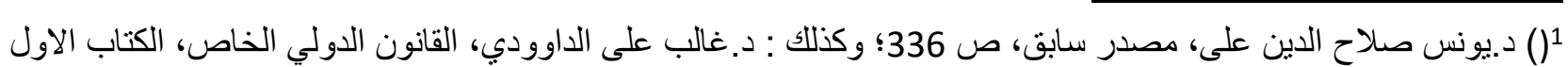

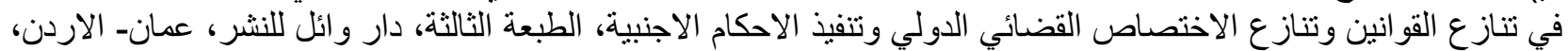

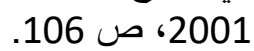

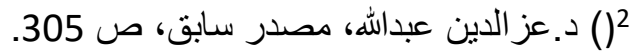

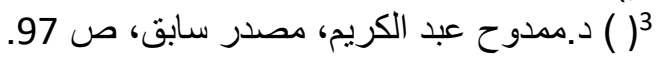

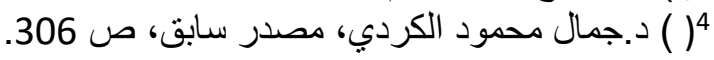


الا في حالات معينة تقرر عدم أنسحاب اثار البطلان الى الماضي بشروط معينة أهمها حسن النية لإحد الزوجين رعاية له و للأو لاد، بحيث يعد الزواج في هذه الفترة زواجاً وهياً أو ظنياً (1). أما الفسخ فهو جزاء يترتب على تخلف شرط من شروط انعقاد الزواج الصحيح أو من شروط لزومهه، أو أي أمر اخر يطرأ يوجب إنهاء الزواج أي ان العلافة بدأت صحيحة لكن طر أت ظروف جعلت من العقد غير صحيح ويحسب مفسوخاً، مثال ذلك الزو اج من محرم، كالاخت من الرضاع، أو زوجة الغير، أو معتدته، وكذلك الزواج من غير شهود، وهذه العلاقة تسمى زو اجاً الى لى ان يتم التفريق بين الزوجين حيث يرتب الدخول بالزوجة وجوب المهر وثبوت النسب، وبعد الفسخ تجب العدة على الزوجة وتنثبت حرمة المصاهرة، و لايثبت الحق في النفقة والمير اث، بخلاف البطلان و الذي هو و العدم سواء لاتترتب عليه اثار ، و لايجب بمقتضاهيا

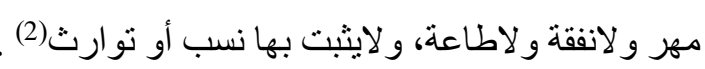
ولكن بالعودة الى المشرع العر اقي، نجد ان المادة التاسعة عشرة في الفقرة الثالثة منها لم يرد بالذكر فيها البطلان أو الفسخ، لذلك لا توجد قاعدة اسناد خاصة به، ولكن بالرجوع الى بعض القو انين كالقانون الدولي الخاص اليو غوسلافي (3) لعام 1983 حيث جاء في المادة الرابعة والثلاثون منه النص على ان عدم صحة الزواج (إنعدامه أو بطلانه) يحكمه القانون الذي يخضع لله إنعقاد الزو اج، وذلك لان أسباب بطلان الزواج نرجع عادة الى تخلف ركن أو شرط من شروط إنعقاده وصحته و هي امور يلزم تو افرها

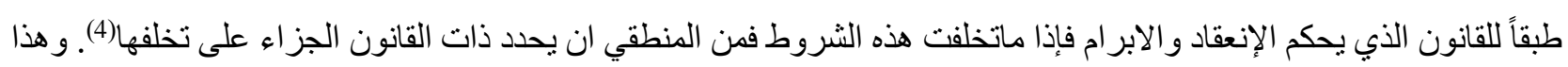

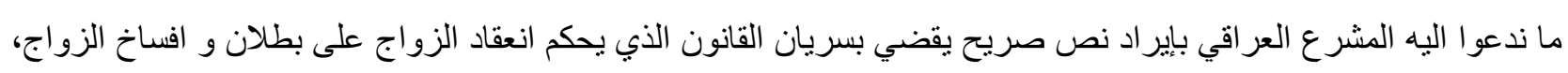
وذلك تماثياً مع مباديء القانون الدولي الخاص الاكثر شيو عاً.

\section{الفرع الثاني \\ مضمون قاعدة الاسناد}

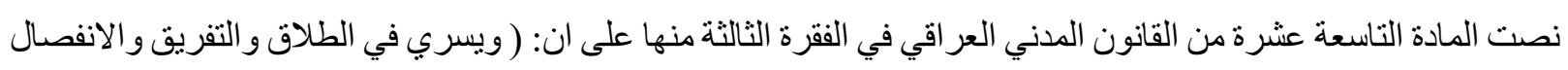
قانون الزوج وقت الطلاق أو وقت رفع الدعوى)، مع مر اعاة نص الفقرة الخامسة من نفس المادة وهي: (في الاحوال المنصوص

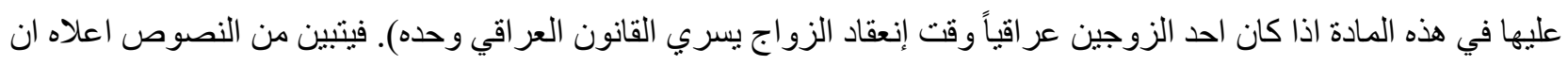

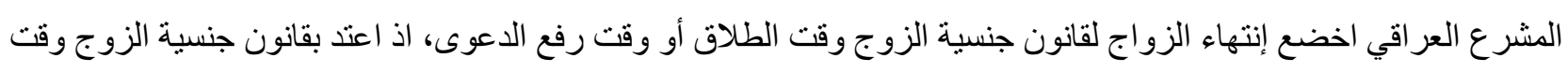

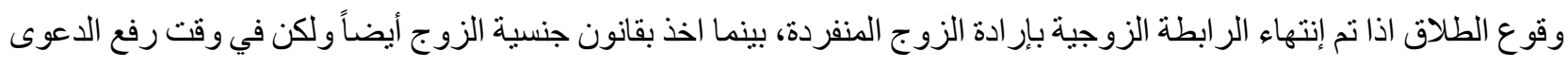
اذا ما تم الانتهاء بالتطليق أو الانفصال. ولكن انتقد البعض هذا الاتجاه على أساس انه يؤدي الى مفاجأة الزوجة بالطلاق أو التطليق وفقاً لاحكام قانون جنسية الزوج

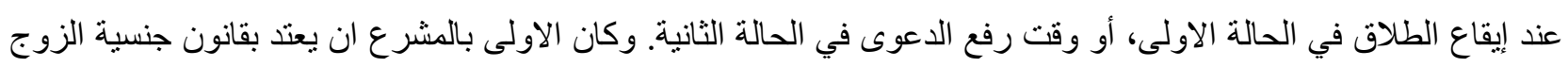

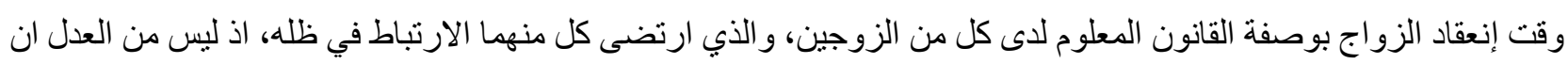

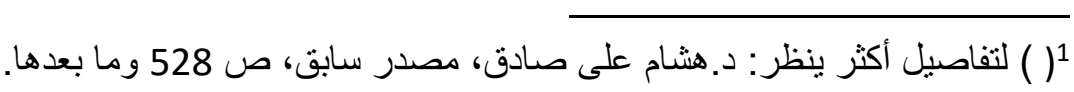

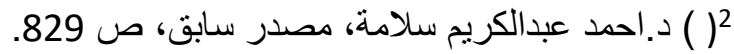

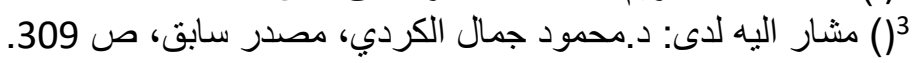

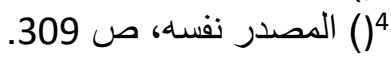


تفاجأ الزوجة بقانون اخر عند تغيير الزوج لجنسيته، وقد يكون هذا القانون أكثر ضرراً بمصالح الزوجة من حيث تيسير الطلاق أو التطليق(1)

كما ان عيب إنفر اد هذا القانون بالحكم من ناحية كون الزواج رابطة مابين طرفين تنشأ وفقاً لقانونيهما، و الو اجب ان لاتنحل

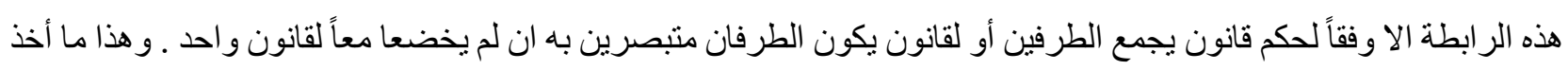

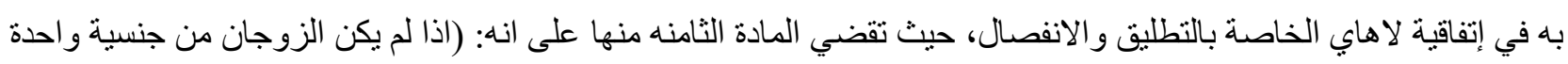
فيكون قانون اخر جنسية مشتركة لهما هو القانون المعتبر بالنسبة لنطبيق المو اد السابقة(وهي المو اد الخاصة بالتطليق و الانفصال) انه هو قانون جنسيتهما)(2). و ان إخضاع الحكم على إنتهاء العلاقة الزوجية لقانونين يجعل الامر أكثر صعوبة عند التطبيق، فما جاء في قضية فير اري خير

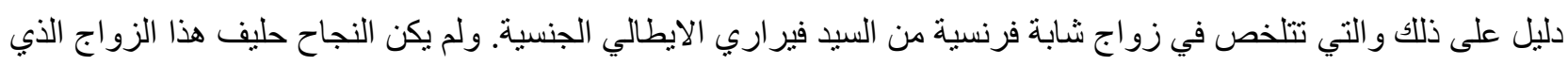
أنتهى بالفرقةو إلتجاء الزوجة الى القضاء طالبة الحكم لها بالطلاق. وبناءاً على تو افر شروط الطلاق الو اردة في القانون الفرنسي فقد لبت المحكمة طلبها وحكمت لها بالطلاق رغم أن قانون الزوج (الايطالي) يمنع إيقاع الطلاق. وقد أدى الاخذ بقانون جنسية كل

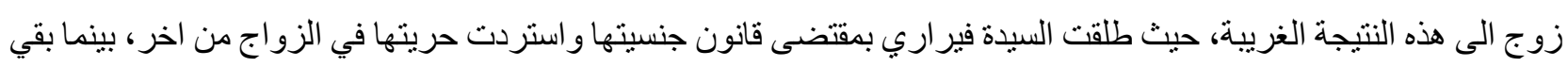

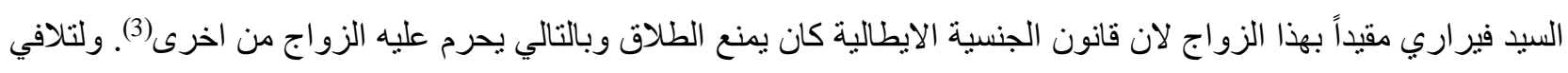

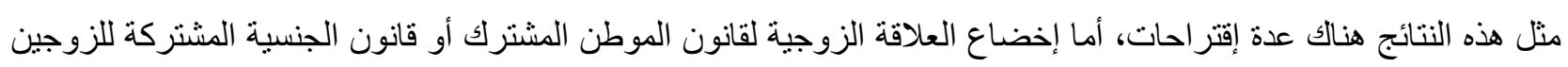
اذا اتحدا في الجنسية عند الزواج.

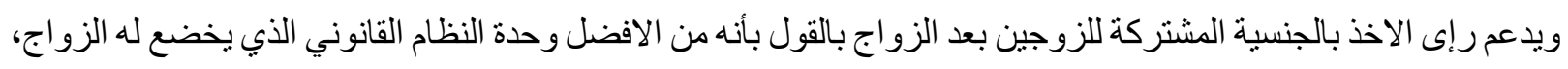

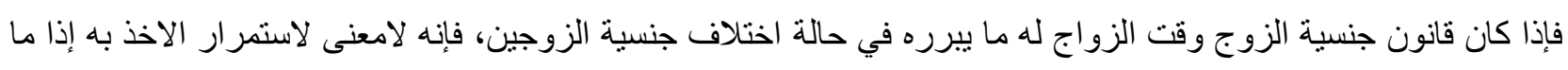

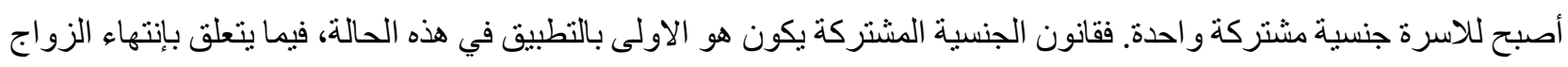
عن قانون جنسية الزوج والذي انقطعت الصلة به و هذا ما اخذ به العديد من تشريعات القانون الدولي الخاص، كالتشريع الالماني المعدل لعام 1986 وكذلك إتفاقية لاهابي لعام 1902 بشأن التطليق حيث كرست هذا الحل (قانون اخر جنسية مشتركة للزوجين) (4). أما في القانون الكويتي فنص في المادة الاربعون من قانون تنظيم العلاقات القانونية ذات العنصر الاجنبي على انه:(بسري على لماتى الطلاق و التطليق و الانفصال قانون اخر جنسية مشتركة كسبها الزوجان أثناء الطلاق أو قبل رفع دعوى بالتطليق أو الانفصال. فإن لم توجد هذه الجنسية المشتركة سرى قانون الزوج وقت إنعقاد الزواج)(5). ونحن بدورنا نؤيد المشرع الكويتي ونناثند المشرع

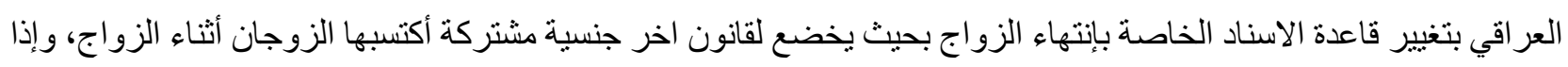

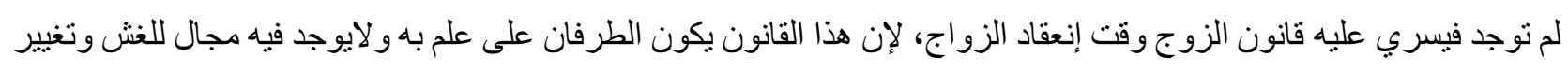
الجنسية كوسيلة لتغيير القانون الواجب التطبيق.

\section{المطلب الثاني}

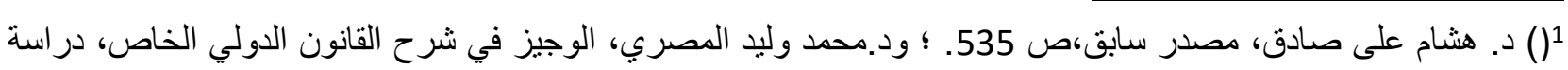

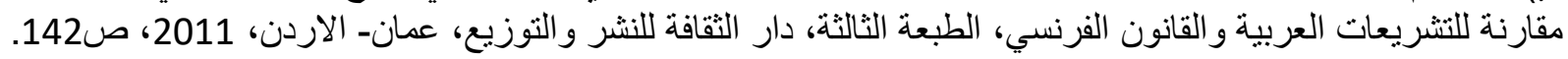

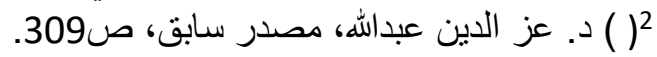

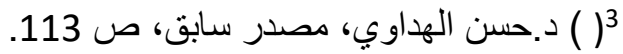

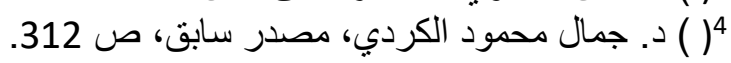

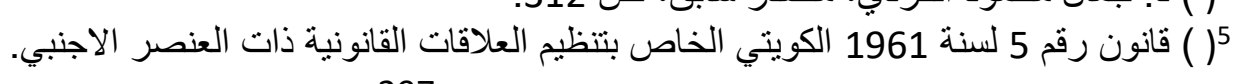




\section{نطاق تطبيق القانون الذي يحكم إنتهاء الزواج}

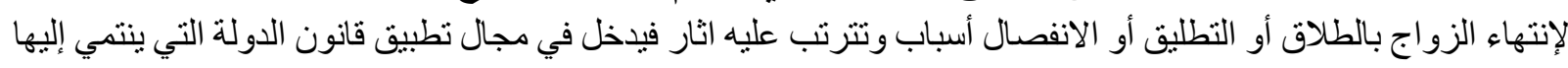
الزوج وقت الطلاق أو وقت رفع الدعوى في شأن التطليق و الانفصال، وتحديد أسباب الطلاق و التطليق و الانفصال، وكذلك الثروط الموضوعية لصحة إيقاع الطلاق، وكذلك كافة المسائل الموضوعية التي تتعلق بإثبات الوقائع التي يستند إليها سبب الطلاق أو ولئو

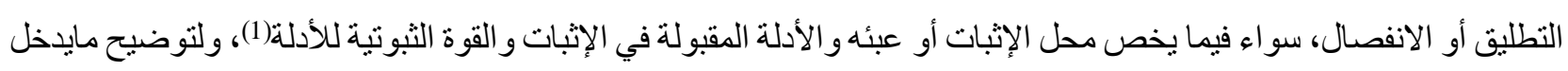

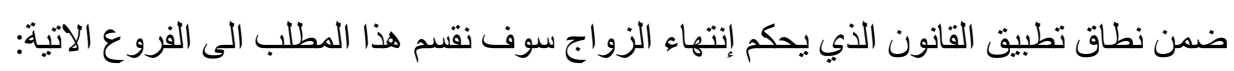

\section{الفرع الاول}

\section{نطاق تطبيق القانون بالنسبة للشروط اللازمة لإنتهاء الزول الإو}

ان قانون جنسية الزوج وقت الطلاق هو الذي يحدد من له الحق في إيقاع الطلاق وكيفية ممارسة هذا الحق، والقيود التي ترد

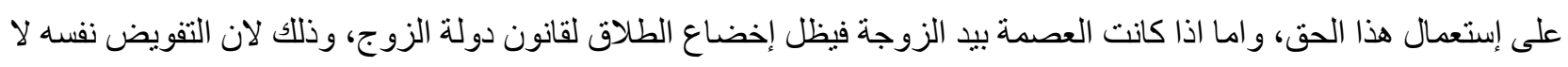

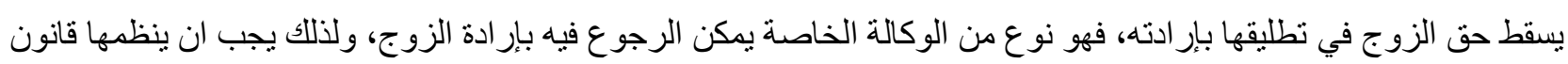
الزوج، وكذلك ما يدخل ضمن معرفة ماهيه شروط ونطاق تللك الوكالة. ويحدد قانون جنسية الزوج وقت رفع الدعوى ايضاً الاسباب التي يتعين تو افرها للحكم بالتطليق وكذللك الحالات التي يمكن

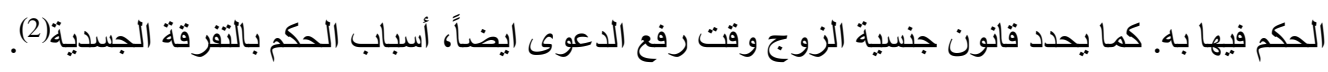

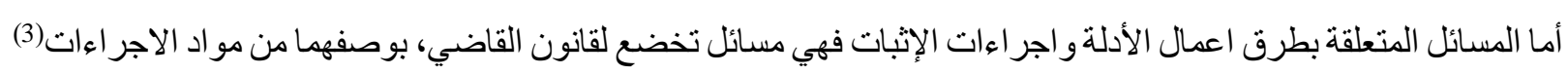
وذللك لان من الامور التي تدخل في صميم فكرة الطلاق و التطليق القو اعد الموضوعية الخاصة بإثبات دعاوي الطلاق و التطليق، حيث يرجع لقانون جنسية الزوج وقت الطلاق أو وقت رفع دعوى التطليق لتحديد وسائل الإثبات ومدى حجيتهاو الئه الية سماع البينة الثخصية وتقديم الدليل الكتابي و غير ها من وسائل الإثبات الاخرى(4).

\section{الفرع الثاني}

\section{نطاق تطبيق قانون إنتهاء الزواج بالنسبة لآثاره}

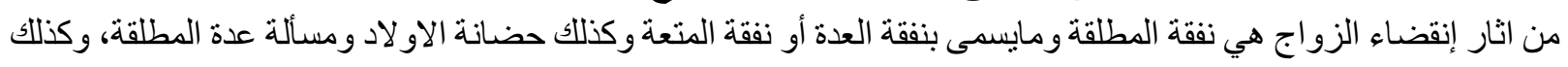
التدابير المستعجلة ويقصد بها النفقة الوقتية للمطلقة و أو لادها. وفي هذا الفرع نحدد ما يدخل ضمن تطبيق القانون الواجب التطبيق على إنتهاء الزواج وما لايدخل كما في التوضيح التالي:

\section{أولاً: نفقة المطلقة (نفقة العدة أونفقة المتعة) وعدتها}

نفقة المطلقة هي التي تجب للمر أة على زوجها السابق، بعد ايقاع الطلاق أو صدور حكم التطليق، حيث تسمى بنفقة العدة ونفقة

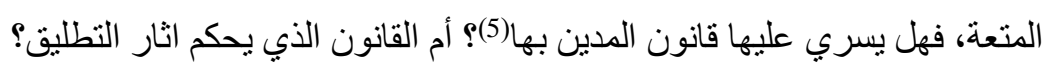

1

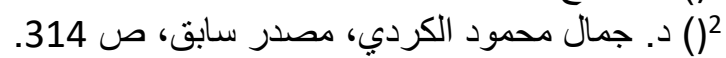

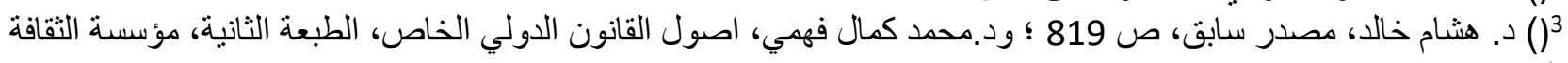

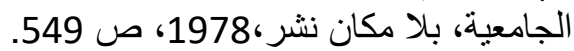

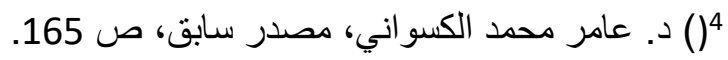
5 ( ) نتص المادة (21) من ألقانون المدني العر اقي على أن: (الالنز ام بالنفقة يسري عليه قانون المدين بها). 
تخضع النفقة الزوجية التي تجب على أحد طرفي الزواج للزوج الاخر لقانون جنسية الزوج وقت الزواج(1) بإعتبار ها أثر من اثار الزواج وذلك من حيث مدى وجوبها والملتزم بهاومقدار ها ومدتها وجز اء الامتناع عن ادائها. ويسري بشأنها كذلك الاستثناء

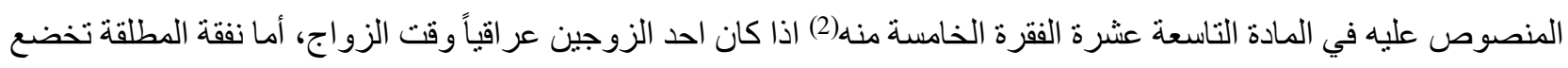
لقانون جنسية الزوج وقت الطلاق أو وقت رفع دعوى التطليق بحسب الحال، وذلك بوصفها من اثار انحلال الرابطة الزوجية. كما

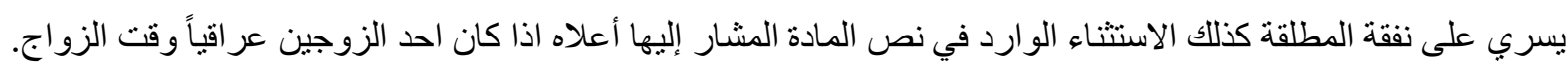

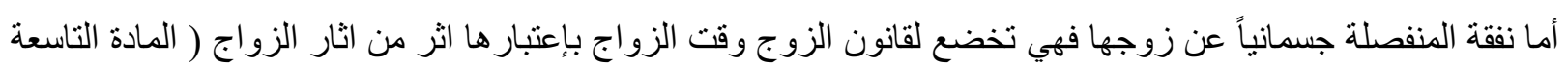

عشرة الفقرة الثانية منه) بإعنبار ان رباط الزوجية مايز ال مسنمر اً، كما ان العلاقة الزوجية تظل قائمة خلال فترة الانفصال(3).

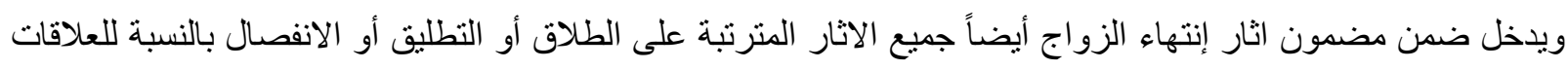

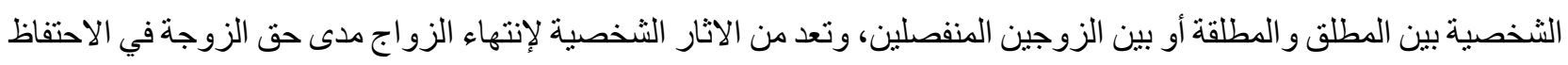

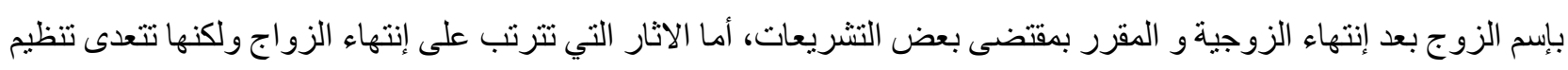
انتهاء حياة الزوجين المشتركة فإنها تخرج عن مجال إعمال قاعدة الاسناد الخاصة بإنتهاء الزو اج بإعتبار ان كلا الطرفين قد أصبح

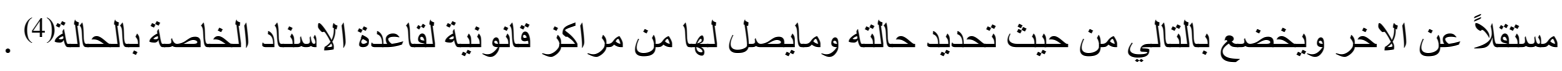
أما بالنسبة لعدة المطلقة أنقسم الفقه بشأن مسألة القانون الواجب التطبئ ونبيق عليها فمنهم من برى اختصاص القانون الذي يحكم

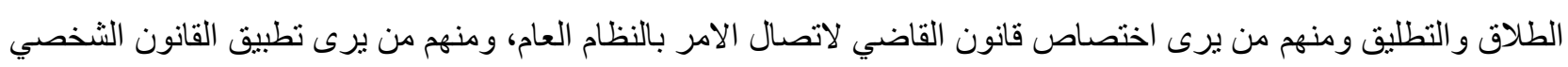

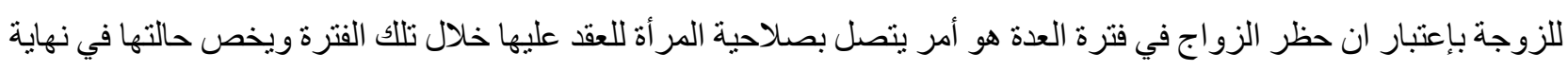

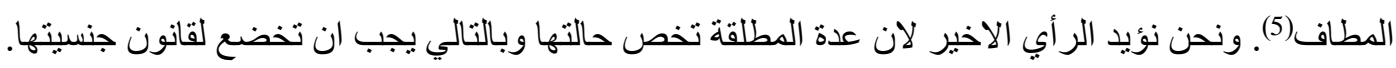

\section{ثنانياً: حضانة الاولاد}

تعرف الحضانة بأنها القيام على شؤون الطفل وكفالته بغرض المحافظة على بدنه و عقله ودينه وحمايته من عو امل الانحر اف

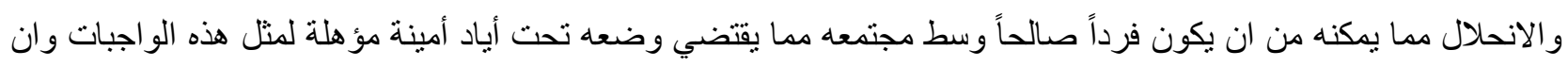

$$
\text { يكون لهم الحق في ذللك وفقاً لقو اعد الثريعة و القانون. }
$$

وتعتبر الحضانة من أهم و أبرز النتائج المترتبة على إنحلال عقد الزواج فهو واعهو واجب على الحاضن وحق للحاضن و المحضون أيضاً ، فإذا وقع الطلاق بين الزوجين فإنه ينتج عن ذلك مباشرة حق للحاضن في طلب الحكم له بحضانة الصغير ، كما ينتج عنه وله

حق على حاضنه يتعلق بحضانته(6) ،

1) تنص المادة (2/19) على أن: (ويسري قانون الدولة التي ينتمي إليها الزوج وقت انعقاد الزواج على الاثار التي يرتبها عقد

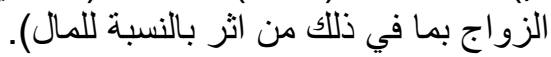

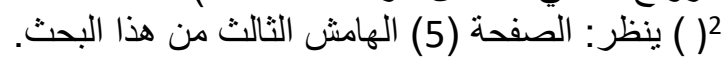

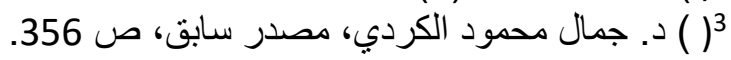
4)

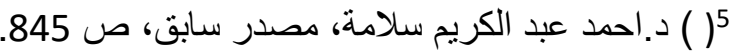

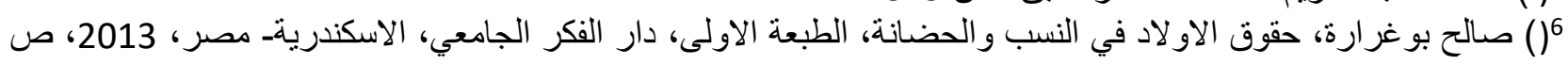


وتظهر مشكلة القانون الواجب التطبيق على حضانة الاولاد عند اختلاف جنسية الوالدين وتباينت وجهات النظر بشأن حلها، فيذهب البعض الى اخضاع الحضانة للقانون الذي يحكم النسب لأنها أحد اثار النسب، أي تطبيق قانون الاب(1) ، وذهب رأب رأي اخر

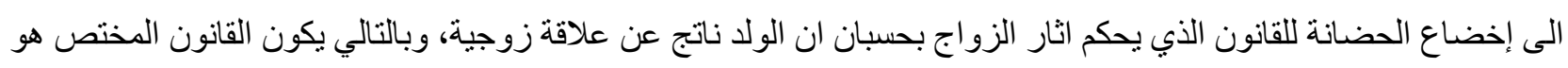

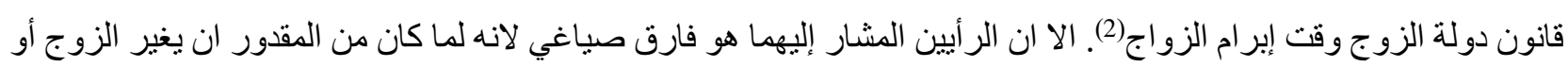

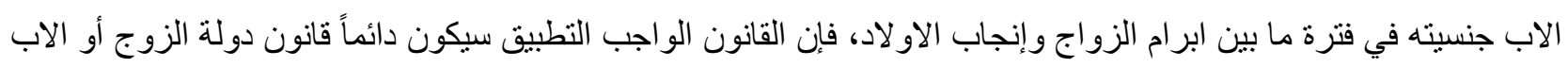

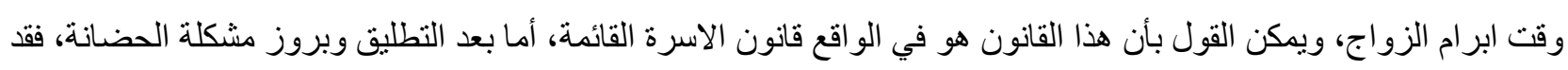
تصدعت الاسرة و لايكون لذلك القانون مايدعم قدرته على تأمين حماية الطفل.

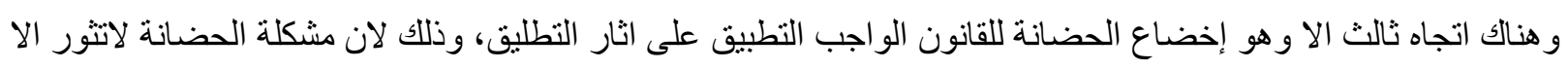

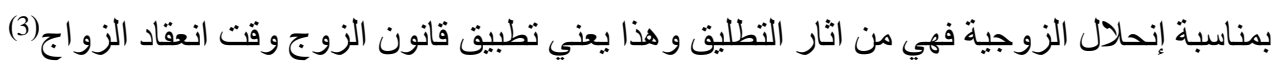

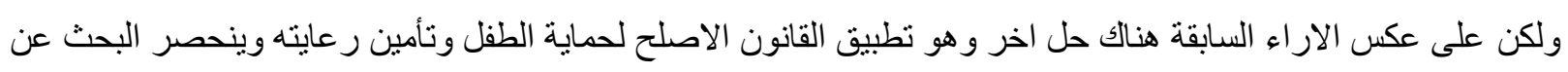
ذللك القانون من بين كل من القانون واجب التطبيق على اثار التطليق، و القانون الثخصي للطفل(4). و هذا الر أب هو الافضل بالنسبة لحماية الطفل ور عاية مصالحه ولذلك ندعو المشرع العر اقي للاخذ بـانه.

ثالثثاً: التدابير المستعجلة(النفقة الوقتية للمطلة وأولادها) هناك عدة تدابير مستعجلة في بعض من الدعاوي لابد من الفصل و إتخاذ القرار فيها لحين الفصل في الدعوى المرفوعة، كذلك

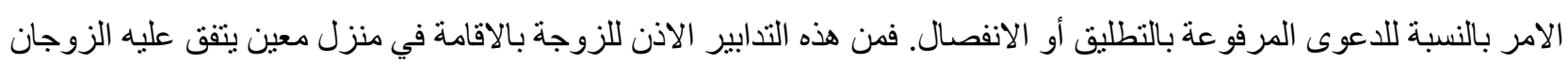

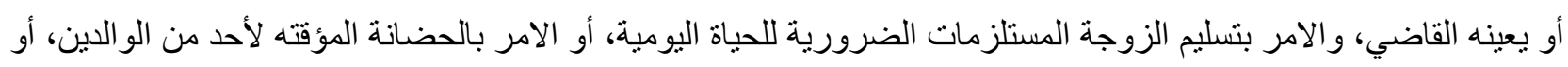

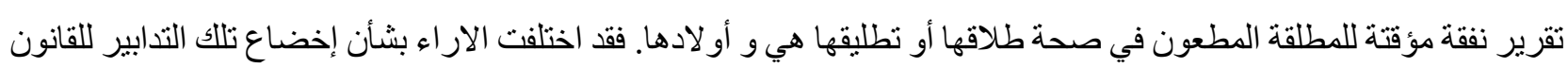

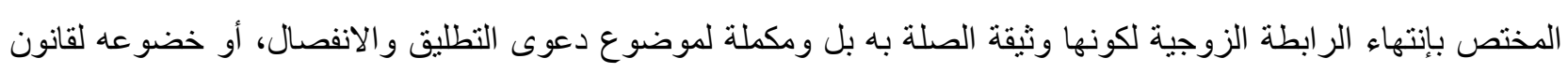
القاضي المختص و الذي نرفع أمامه الدعوى بشأنها(5). ولكن نرى ان خضوعه لقانون القاضي أيسر في التطبيق لسببين وذلك لمعرفة القاضي و إلمامه بقانو نه أو لاً، ولأن موضوع النوع النزاع غير محسوم ويجب تحديد قاعدة الاسناد خلال مر احل الدعوى ثم تطبيقه على تللك التدابير المستعجلة وهذا ينافي مايتطلبه تللك التدابير من السر عة ثانياً.

\section{المطاب الثالث \\ النظام العام والقانون الأجنبي الأي يحكم إنتهاء الزواج}

ان فكرة النظام العام هي مجموعة القواعد القانونية التي لاتتسامح دولة القاضي في الخروج عن أحكامها، وذللك سواء تعلق

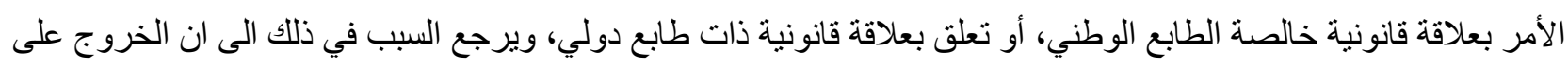

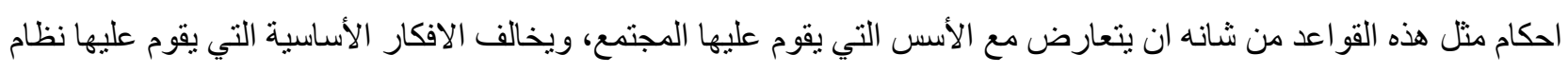

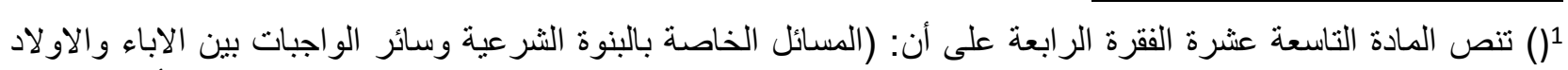

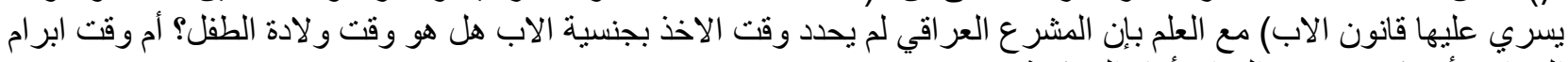

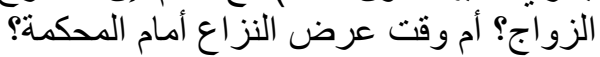

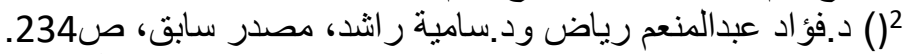

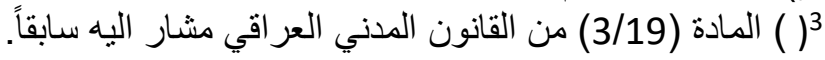

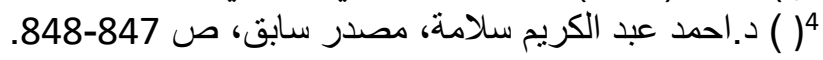

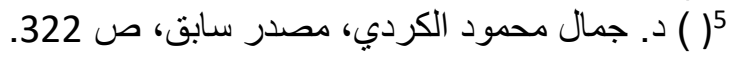


المجتمع الاعلى في مجتمع القاضي لاسيما في علاقات الاحوال الثخصية، فعندئذ يتحتم على القاضي ان يمتنع عن تطبيق القانون

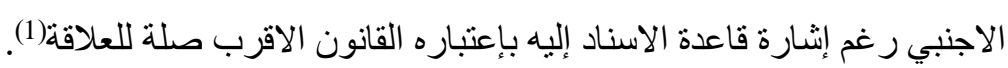

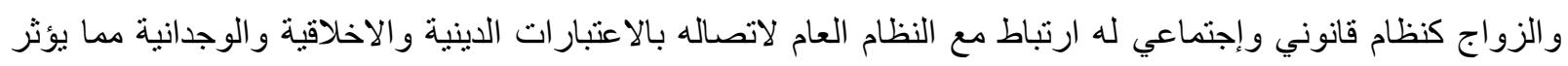

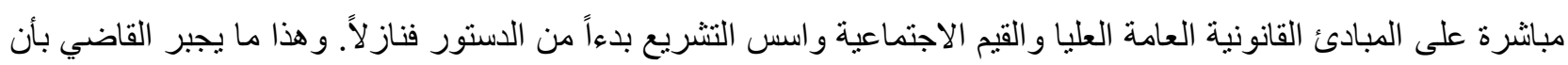

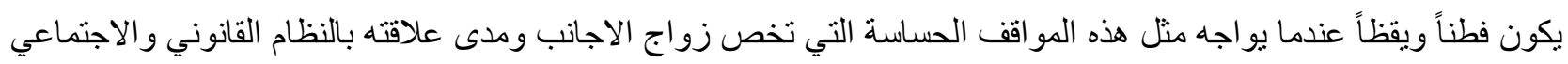
لدولة المحكمة(2). الا ان هذه المبادئ الموجودة في النظام القانوني لدولة ما متغيرة بتغيير المفاهيم و القيم الاخلاقية والقانونية في كل دولة، إضافة الى ان قو انين بعض الدول تقر طرقاً لانحلال رابطة الزوجية قد تنكر ها أنظمة قانونية اخرى، كما هو الثأن فيما يتعلق بالطلاق بالار ادة المنفردة المعروف في الدول الاسلامية وتجهله قو انين الدول الاوربية.

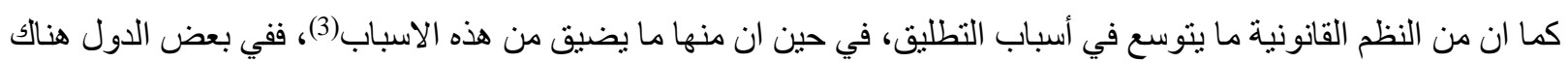

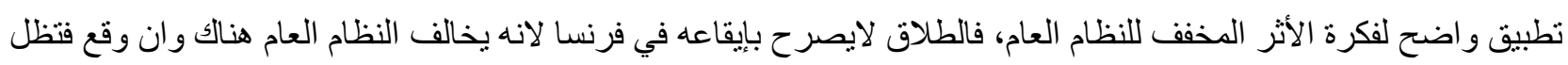

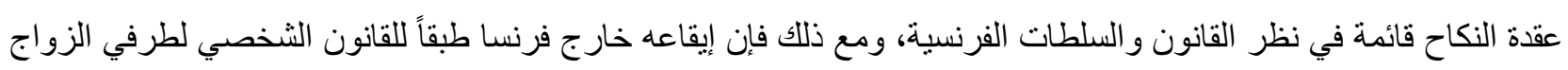

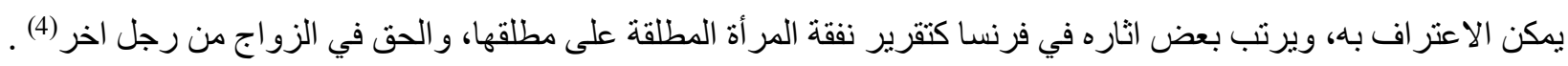

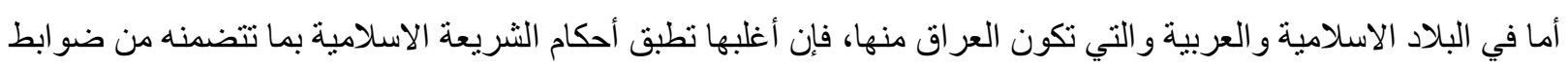
أكثر وضوحاً وأستقر اراً فيما يتعلق بالدفع بالنظام العام حيث يركز القضاء عند بحث مشكلات إنتهاء الرابطة الزوجية على تحديد ديانة الاطر اف من الاجانب، و على ذلك يستبعد القو انين الاجنبية التي تقضي مثلاً بحرمان الزوج المسلم من حقه في الطلاق مطلقاً،

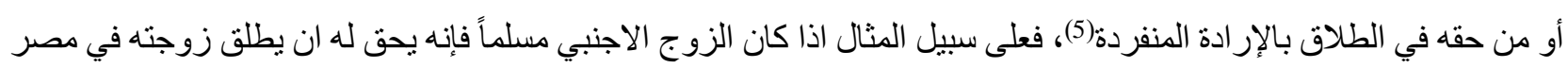
أو العراق حتى لو كان قانون جنسيته يحرمه من هذه الرخصة على اساس ان تمتع المسلم بالحقوق المقررة في الثريعة الاسلامية

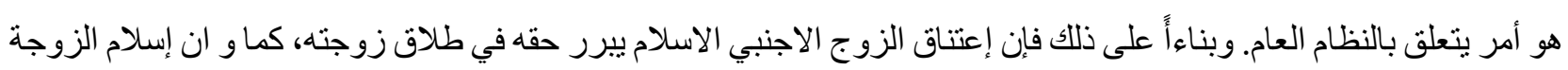

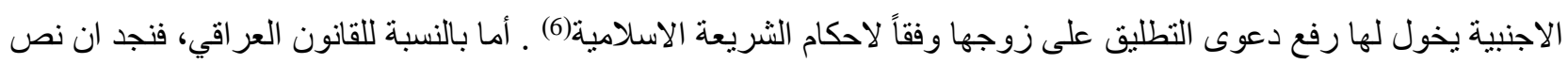
المادة الثانية و الثلاثون من القانون المدني جاء بصورة عامة اذ تنص على :( لايجوز تطبيق احكام قانون اجنبي قررته النصوص

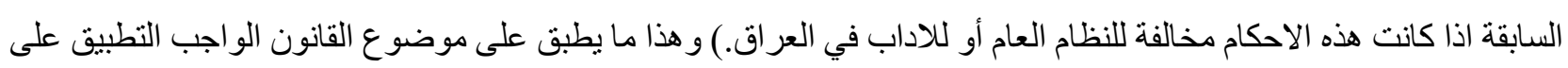

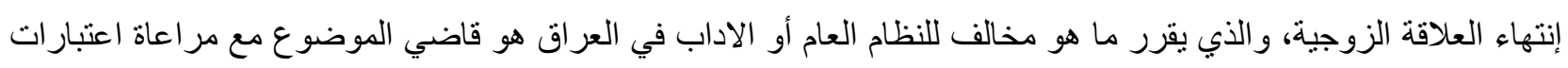
وظروف المجتمع العر اقي في وقت عرض وضلاء النزاع أمامه.

1() د. صلاح الدين جمال الدين، فكرة النظام العام في العلاقات الخاصة الدولية بين القو انين الوضعية و الثريعة الاسلامية، الطبعة

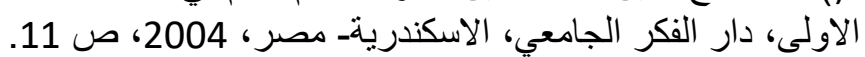

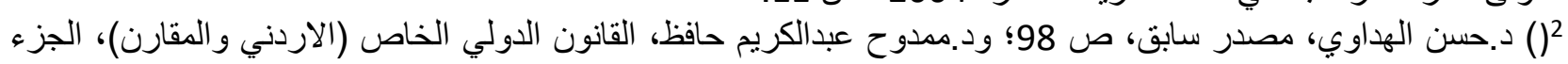

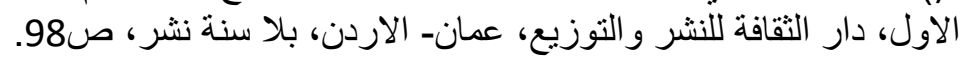

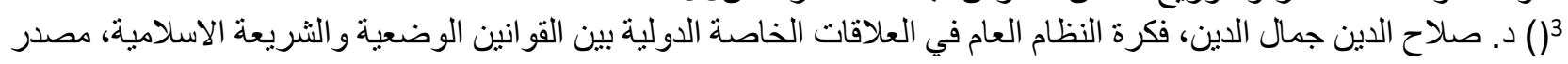

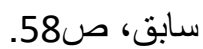
4) د. دمال محمود الكردي، مصدر سابق، ص 325. 325. حيث ان المشرع الفرنسي يظهر أكثر حرصاً في تطبيق القانون الفرنسي

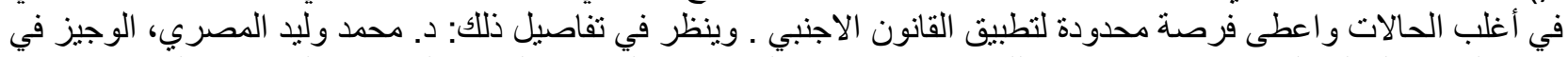

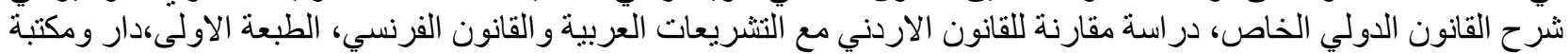

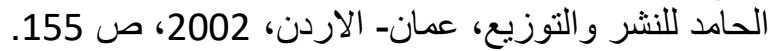

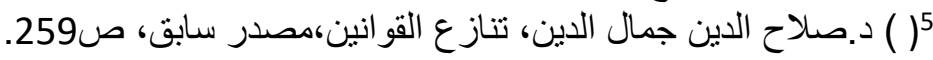

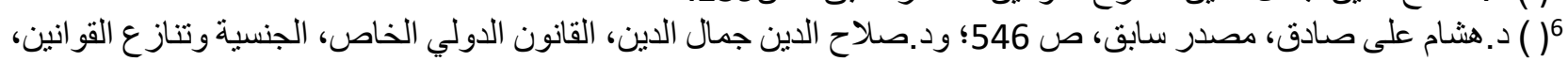

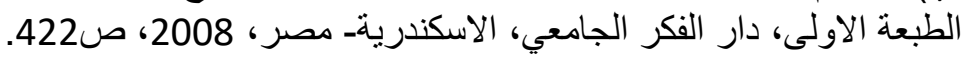




\section{الخاتمة}

الملاحظ من خلال هذا البحث المنو اضع آلّي أجريناه، أن لقو اعد التناز ع أهمية كبرى في حل النزاعات الدولية الخاصة. ويثير الزواج المختلط مشاكل عويصة داخل الأنظمة القانونية، لذلك سعت الدول الى تنظيمه بقو اعد قانونية لتحكم هذه المناز عات التي يتخلاها عنصا أجنبي، ويبلغ هذا التنازع حده خاصة في مجال الزواج و انحلاله.

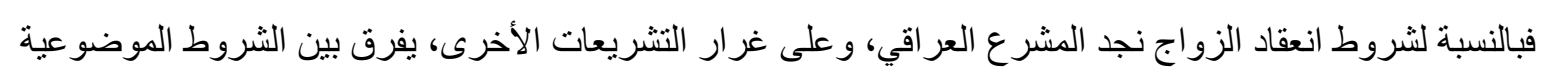

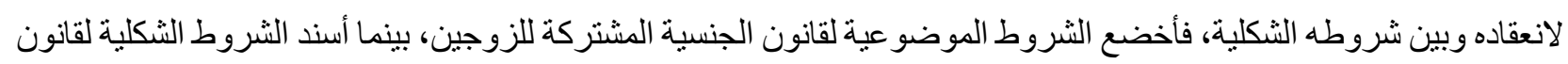
محل الإبرام، إضافة إلى ضوابط إسناد احتياطية تحكم هذه الثروط الثكلية، أما لقانون الجنسية المشتركة. فتوجد صعوبة فئنة في تحديد هذه الثروط، فيما إذا كانت من قبيل الثروط الموضو عية أو من قبيل الثروط الثنابط الثكلية، في هذه الحالة ترك الأمر للقاضي المعروض أمامه النزاع كسلطة تقديرية في تحديدها طبقا لقانونه الوطني. في ضوء هذا البحث توصلنا الى عدد من الإستتناجات وسوف نقدم عدداً من التوصيات، ونذكر فيما يلي أهم هذه فئه الإستنتاجات و التوصيات:

\section{اولاً: الاستثتاجات}

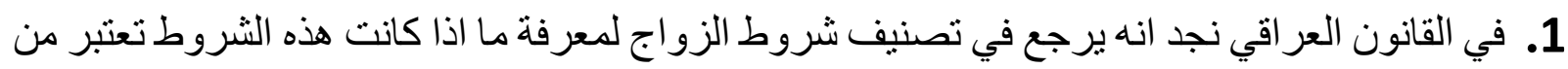
الشروط الشكلية ام من الشروط الموضو عية للقانون العر اقي لان هذان هذا التصنيف من مسائل التكييف

$$
\text { و الاختصاص فيه يرجع لقانون القاضي. }
$$

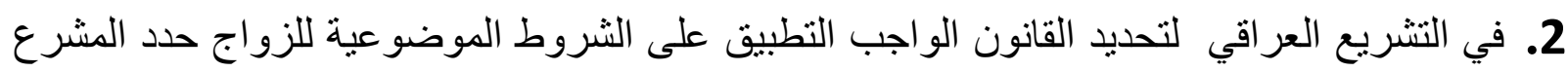

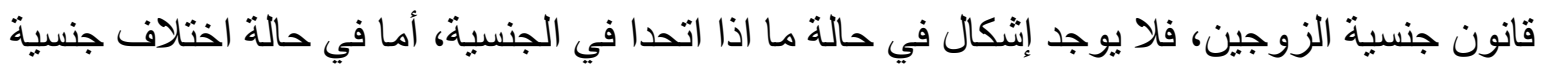

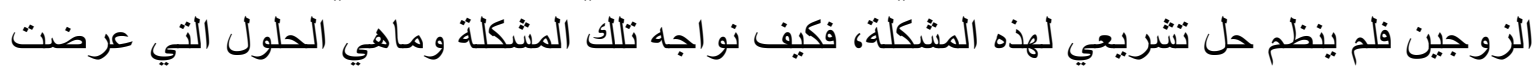

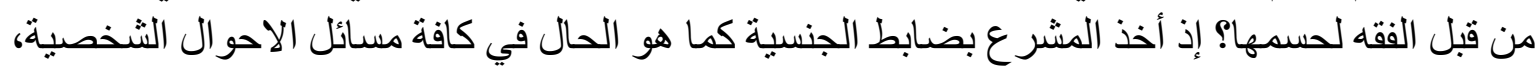
ولم تنص على تحديد وقت معين لاسناد الشروط الموضو عية الى قانون كل من الزوجين. و هذا يعد خلاد

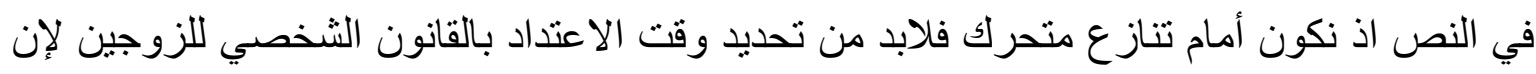

$$
\text { الجنسية بمكن تغيير ها. }
$$

3. أن الثكلية في العقد عبارة عن اسلوب محدد للتعبير عن الإرادة المفروضة، أبي أنه قيد على الإر ادة،

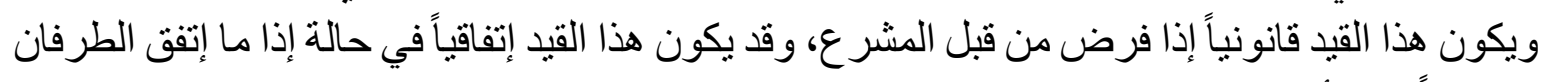

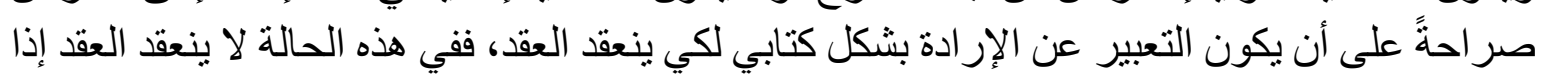
لم يكتب. 4. أن الثكلية تعد إستثناء من مبدأ الرضائية في العقود فيجب أن ينص عليها صر احةً.

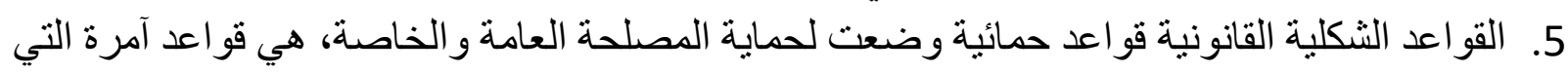
مخالفتها تستوجب جز اء ألا و هو بطلان العقد وأن ذلك يعد من النظام العام الذي لا يمكن للقاضي الحياد

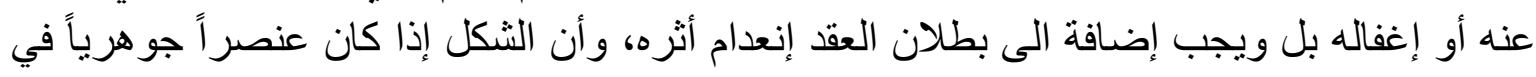
العقد الثكلي فإنه لا يغني بأبي حال عن الإر ادة بل بؤكدها. 
6. ان قاعدة خضوع شكل العقد الى قانون مكان إبر امه أريد بها التيسير على المتعاقدين من إجر اء تصر فات صحيحة أينما وجدوا، إذ يسهل الوقوف على الثكل المقرر في قانون البلد الذي إنعقد فيه العقد.

\section{ثانياً: التوصيات}

1. تطبيق القانون الاصلح لحماية الطفل وتأمين رعايته وينحصر البحث عن ذللك القانون من بين كل من

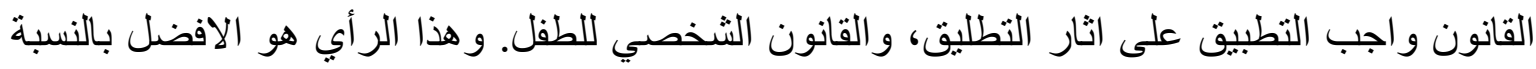

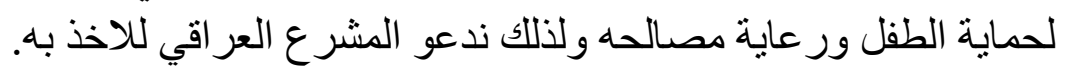

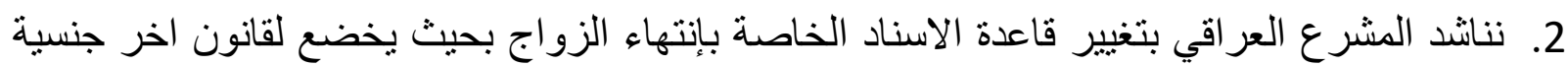

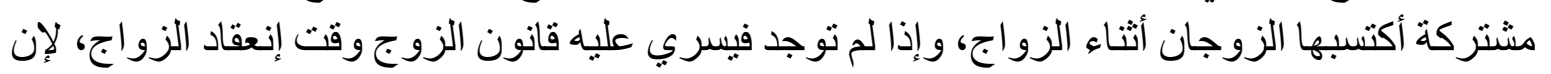
هذا القانون يكون الطرفان على علم به ولا يوجد فيه مجال للغش وتغيير الجنسية كوسيلة لتغيير القانون الو اجب التطبيق.

\section{المصادر}

$$
\text { أولاًً : الكتب }
$$

1. د.ابر اهيم احمد ابر اهيم، القانون الدولي الخاص، تنازع القوانين، دار النهضة العربية، القاهرة- دصر،

2. د.احمد رفعت مهدي خطاب، الإثبات أمام القضاء الدولي، الطبعة الاولى، دار الفكر الجامعي، الاسكندرية- مصر، 2009. 
3. د.احمد عبدالكريم سلامة، علم قاعدة التنازع و الاختيار بين الثرائع اصولاً و منهجاً، الطبعة الاولى، مكتبة الجلاء الجديدة، المنصورة- مصر ، 1996.

4. د. حسن الهداوي، تنازع القوانين، المبادئ العامة و الحلول الوضعية في القانون الاردني، در اسة مقارنة، الطبعة الاولى، دار الثقافة للنشر والتوزيع، بيروت، لبنان، 2005.

5. د.جمال محمود الكردى، تتازع القوانين، منشأة المعارف، الاسكندريةــ مصر، 2009.

6. د.سامي بديع منصور ود. عكاشة عبد العال، القانون الدولي الخاص، الدار الجامعية، بيروتـ لبنان، بلا سنة نشر.

7. د.سامي بديع منصور ود.أسامة العجوز، القانون الدولي الخاص، الطبعة الثالثة، مكتبة زين الحقوقية والادبية، بيروت- لبنان، 2009.

8. صالح بوغرارة، حقوق الاولاد في النسب والحضانة، الطبعة الاولى، دار الفكر الجامعي، الاسكندريةـ مصر، 2013.

9. د.صلاح الدين جمال الدين، تنازع القوانين،در اسة مقارنة بين الثريعة والقانون، الطبعة الاولى،منشأة المعارف، الاسكندرية- مصر ، 2006 .

10. د.صلاح الدين جمال الدين، مشكلات ابرام الزواج في القانون الدولي الخاص، دار الفكر الجامعي، الاسكندرية- مصر، 2010.

11. د.صلاح الدين جمال الدين، قانون العلاقات الخاصة الدولية، دراسة في ضوء فقه الشريعة الاسلامية، الطبعة الاولى، دار الفكر الجامعي، الاسكندرية- مصر،2006.

12. د. صلاح الدين جمال الدين، فكرة النظام العام في العلاقات الخاصة الدولية بين القوانين الوضعية و الثريعة الاسلامية، الطبعة الاولى، دار الفكر الجامعي، الاسكندرية- مصر، 2004.

13. د.صلاح الدين جمال الدين، القانون الدولي الخاص، الجنسية وتناز ع القوانين، الطبعة الاولى، دار الفكر الجامعي، الاسكندرية- مصر، 2008.

14. د.عامر محمد الكسو اني، تنازع القوانين، الطبعة الاولى، دار الثقافة للنشر والتوزيع، عمان- الاردن، 
15. د. عبد الرسول عبد الرضا الاسدي، القانون الدولي الخاص، الطبعة الاولى، مكتبة السنهوري، بغدادالعراق، 2015.

16. د.عز الدين عبد الله، القانون الدولي الخاص، الجزء التاني، الطبعة التاسعة، الهيئة المصرية العامة للكتاب- القاهرة، 1986.

17. د. غالب على الداودي، د.حسن الهداوي، القانون الدولي الخاص، الجزء الثاني، مطبعة وزارة التعليم

$$
\text { العالي و البحث العلمي، بغداد- العراق، } 1988 .
$$

18. د. غالب على الداودي، القانون الدولي الخاص، تنازع القوانين، الطبعة الاولى، دار الثقافة للنشر

$$
\text { و التوزيع، عمان- الاردن، } 2011 .
$$

19. د. غالب على الداودي، القانون الدولي الخاص، الكتاب الاول في تنازع القوانين وتنازع الاختصاص

القضائي الدولي وتنفيذ الاحكام الاجنبية، الطبعة الثالثة، دار وائل للنشر، عمان- الاردن، 2001.

20. د.فؤاد عبد المنعم رياض ود.سامية راثد، تنازع القو انين و الاختصاص القضائي الدولي واثار الاحكام الاجنبية، دار النهضة العربية، القاهرة- مصر،

21. د.فؤاد ديب، القانون الدولي الخاص، تنازع القو انين ،مطبعة جامعة دمشق، دمشق، سوريا، بلاسنة نشر.

22. د.محمد كمال فهمي، اصول القانون الدولي الخاص، الطبعة الثانية، مؤسسة الثقافة الجامعية، بلا مكان نشر، 1978.

23. د.محمد وليد المصري، الوجيز في شرح القانون الدولي الخاص، در اسة مقارنة للتشريعات العربية و القانون الفرنسي، الطبعة الثالثة، دار الثقافة للنشر والتوزيع، عمان- الاردن، 2011.

24. د.ممدوح عبدالكريم حافظ، القانون الدولي الخاص (الاردني والمقارن)، الجزء الاول، دار التقافة للنشر و التوزيع، عمان- الاردن، بلا سنة نشر.

25. د. ممدوح عبدالكريم ،تنازع القوانين، الطبعة الاولى، دار الثقافة للنشر و التوزيع، عمان- الاردن، .2005 
26. د. هادي رشيد الجاوشلي، الوضع القانوني للأجانب في العراق، مطبعة المعارف، بغداد- العراق،

27. د. هشام خالد، القانون الواجب التطبيق على شكل الزواج، منشأة المعارف، الاسكندريةـ مصر، $(2005$

28. د. هشام خالد، القانون الدولي الخاص،الطبعة الاولى، دار الفكر الجامعي، الاسكندريةــ مصر، 2014 29. د. هشام على صسادق، تنازع القوانين، منشأة المعارف، الاسكندرية، مصر، 1997. 30. د. يونس صلاح الدين على، القانون الدولي الخاص، الطبعة الاولى، مكتبة زين الحقوقية و الادبية، بيروت- لبنان، 2016.

ثانياً: القوانين 1. القانون المدني العر اقي رقم (40) لسنة 1951 المعدل. 2. قانون الجنسية العر اقية رقم 26 لسنة 2006. 3. قانون الإثبات العر اقي رقم (107) لسنة 1979 المعدل. 4. القانون رقم 5 لسنة 1961 الكويتي الخاص بتتظيم العلاقات القانونية ذات العنصر الاجنبي. 5. قانون الاحو ال الثخصية العر اقية رقم 188 لسنة 1959 المعدل.

الملخص

لقد تنّّ البحث عن موضوع القانون الواجب التطبيق على إنعقاد الزواج و إنتهائه في القانون المدني العر اقي، وذللك من خلال توضيح موضوع الشروط الموضوعية والشروط الثكلية، وكذلك دراسة مواضيع إنتهاء الزواج و القانون الواجب التطبيق عليه. وحاولنا في در استتا أن نبين كيفية معالجة القانون المدني العر اقي للقانون الواجب التطبيق على انعقاد الزو اج و إنتهائه من خلال شر حو تحليل النصوص القانونية المتعلقة بالموضوع في نطاق القانون المدني العر اقي. 
و الجدير بالذكر ، أن المجال الخصب لتنازع القو انين يكون خاصة في المسائل الأسرية نظر الاختلاف عقائد وخصوصيات الأفر اد. و أمام هذا الوضع يثير الزو اج مشاكل عدة من حيث انعقاده والآثار المترتبة عليه، و الأمر كذلك بالنسبة لانحلال الزواج والآثار الناجمة عنه.

لإستيعاب كل ما ورد أعلاه قسمنا بحثنا الى مبحثين، تطرقنا في المبحث الأول لموضوع القانون الواجب التطبيق في المو اضيع المتعلقة بإنعقاد الزواج ومشكلاته في ثثلاثة مطالب شرحنا الثروط الموضو عية للزواج و المو اضيع المتعلقة بها في المطلب الأول، وفي الثاني بحثنا عن الثروط الثكلية والقانون الواجب التطبيق عليها، وخصصنا المطلب الثالث لإثبات الزواج و القانون الواجب التطبيق عليه. وكرسنا المبحث الثاني لإنتهاء الزواج و المو اضيع المتعلقة به في قو اعد الأسناد، وقسمناه الى ثلاثة مطالب، تناولنا في المطلب الأول قاعدة الاسناد الخاصة بإنتهاء الزو اج، وخصصنا الثاني لنطاق تطبيق القانون الذي يحكم إنتهاء الزو اج، وكرسنا المطلب الثالث والأخير للنظام العام والقانون الأجنبي الذي يحكم إنتهاء الزواج، وذلك وصولاً لخاتمة تتضمن النتائج و التوصيات. 


\section{يوخته}

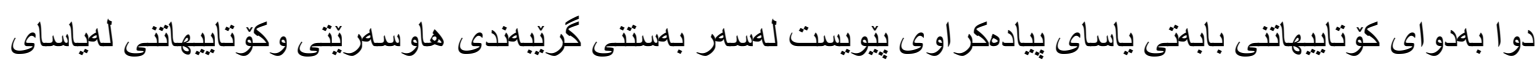

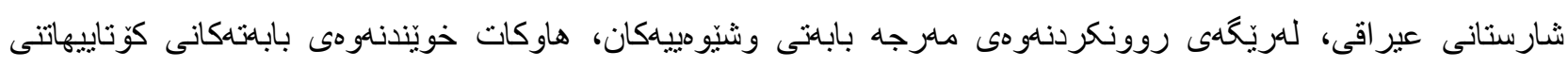

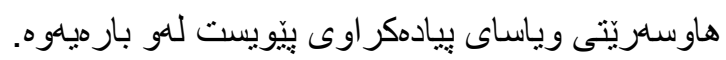

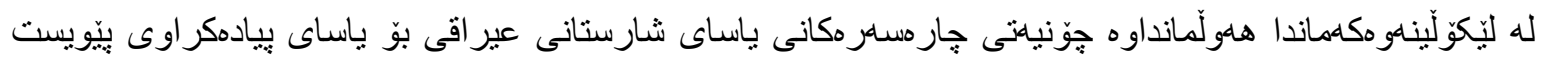

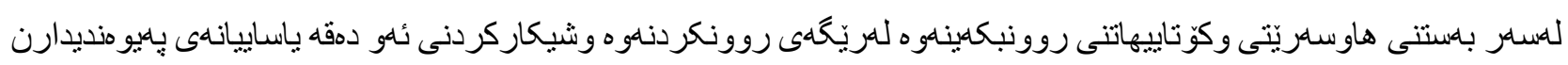

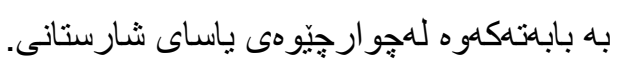

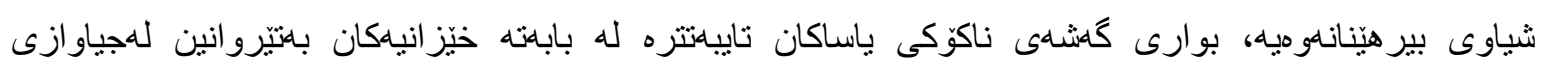

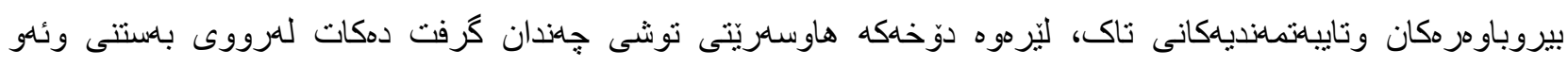

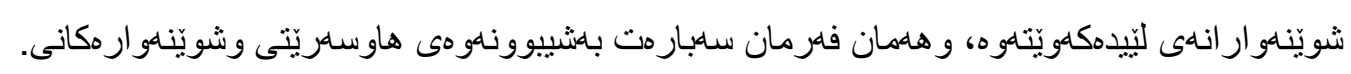

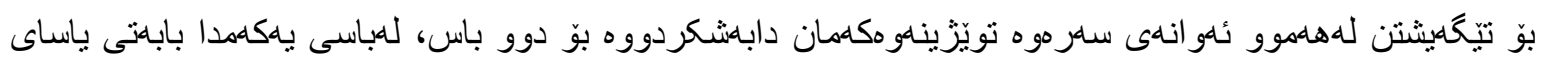

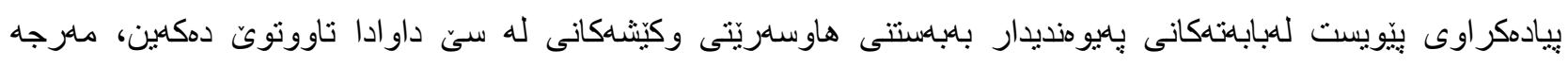

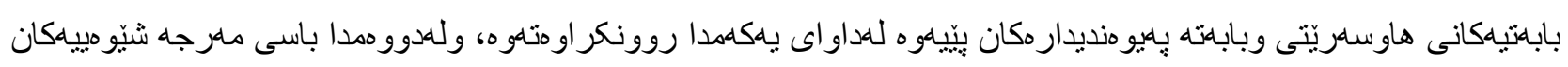

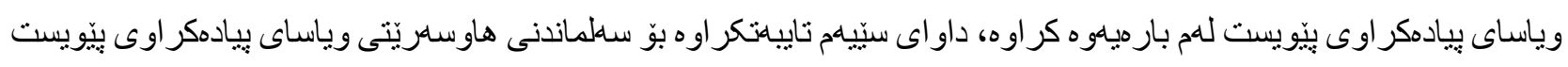

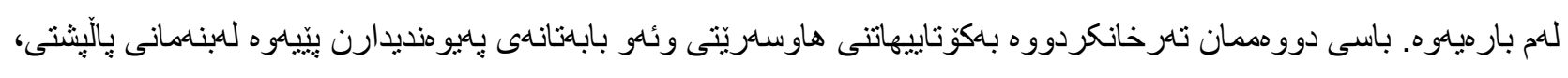

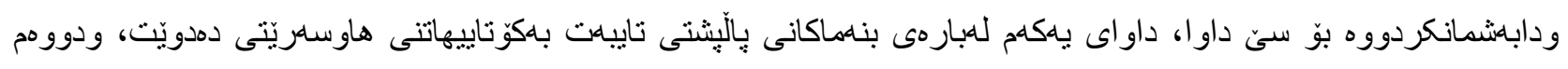

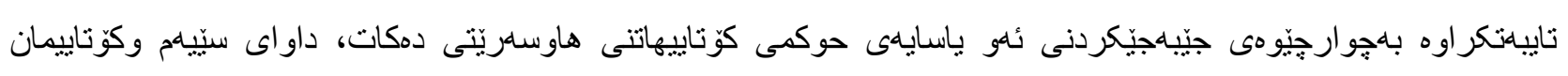

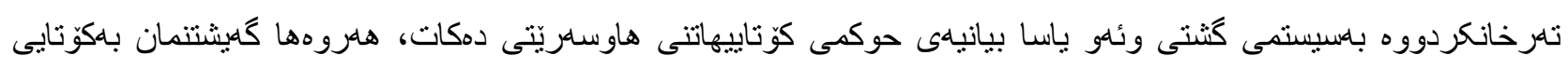

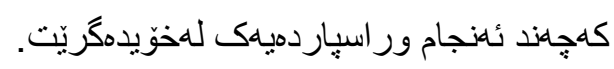




\begin{abstract}
This research is conducted on the subject of applicable law on contracting marriage and its termination in the Iraqi civil law by clarifying the subject of substantive and formal conditions, as well as studying the topics of marriage termination and the law applicable to it. This paper tried to explain how the Iraqi Civil law deals with the law applicable to the contracting of marriage and its termination by clarifying and analyzing the relevant legal texts within the scope of the Iraqi Civil Code.
\end{abstract}

It is worth mentioning that the area of conflict of laws is happening particularly in family matters because of the different beliefs and characteristics of individuals. In such a situation, marriage raises a number of problems in terms of contracting and its implications, as well as the dissolution of marriage and the resulting impact.

To comprehend the above- mentioned, this research is divided into two sections. The first section addresses the law applicable to the subjects related to contracting of marriage and its problems in three subsections. The substantive conditions of marriage and the related topics are explained in the first demand. In the second demand, the formal conditions and the law applicable to them is spelled out. Moreover, third demand is assigned to prove of marriage and the law applicable to it.

We devoted the second section to the ending of marriage and related topics in the rules of attribution, and divided into three demands. The first demand got across the attribution rules of ending the marriage, and the second demand is assigned to the scope of application of the law governing the termination of marriage. Finally, the third demand is dedicated to the public order and foreign law governing the termination of marriage, leading to a conclusion containing findings and recommendations. 